\title{
Miller Fonksiyon ve Katılım Ölçeği: 48-95 ay arası çocuklar için geçerlik ve güvenirlik çalışması*
}

\author{
Miller Function and Participation Scales: The study of validity and \\ reliability for children aged 48-95 months
}

\begin{abstract}
Makale Geçmişi
Geliş : 10 Mayıs 2019

Düzeltme : 24 Haziran 2019

Kabul : 23 Temmuz 2019

Çevrimiçi : 25 Temmuz 2019
\end{abstract}

\section{Makale Türü}

Araștırma Makalesi

\author{
Hande Usbaş ${ }^{1}$, Rengin Zembat ${ }^{2}$
}

\begin{abstract}
Öz: Erken çocukluk dönemi motor becerilerin yeterlilik ve gelişimi için kritik bir dönemdir. Çocukların motor gelişimlerini anlamak ve uygun planlamalar yapabilmek amaciyla motor gelişimin değerlendirilmesi gereklidir. $\mathrm{Bu}$ araştırmada, $48-95$ ay arası çocukların motor gelişimlerini değerlendirmek amaciyla Miller Fonksiyon ve Katılım Ölçeği'nin Türkçe formunun geçerlik ve güvenirlik çalışması yapılmıştır. Araştırmanın çalışma grubunu 48-95 ay arası motor gelişim gecikmesi gösteren grup dâhil olmak üzere toplam 262 çocuk oluşturmaktadır. Araştırma verileri; araştırmacı tarafindan oluşturulan kişisel bilgi formu ve Miller Fonksiyon ve Katılım Ölçeği kullanılarak toplanmıştır. Uyum geçerliğini belirlemek amacıyla Gazi Erken Çocukluk Gelişimi Değerlendirme Aracı ve Frostig Gelişimsel Görsel Alg1 Testi kullanılmıştır. Miller Fonksiyon ve Katılım Ölçeği’nin geçerlik çalışması kapsamında yapı geçerliği, diğer değişkenlerle olan ilişkisi ve klinik ayırt edici geçerliği kanıtlanmıştır. Güvenirlik çalışması kapsamında, iç tutarlılığı, test-tekrar test güvenirliği ve bağımsız değerlendiriciler arası korelasyon katsayısı hesaplanmıştır. Araştırma sonuçları göz önünde bulundurulduğunda, Miller Fonksiyon ve Katılım Ölçeği Türkçe formunun 48-95 ay arası çocuklar için geçerli ve güvenilir bir ölçme aracı olduğu görülmüştür.
\end{abstract}

Anahtar Kelimeler: Motor Gelişim; Miller Fonksiyon ve Katılım Ölçeği; Değerlendirme

\section{Article History \\ Received : 10 May 2019 \\ Revised : 24 June 2019 \\ Accepted : 23 July 2019 \\ Online : 25 July 2019}

\section{Article Type}

Research Article

Abstract: Early childhood is a critical period for development and proficiency of motor skills. Motor development of children should be assessed in order to understand the concept, and if necessary, plan ahead accordingly. In this study, a validity and reliability research was carried out for a Turkish translation of Miller Function and Participation Scales in an effort to assess motor development of children aged 48-95 months. The study group consists of a total of 262 children aged 48-95 months, including a group of children with delayed motor development. The study data were gathered with a personal information form created by the researcher, as well as with Miller Function and Participation Scales. Gazi Early Childhood Development Assessment Tool and Frostig Developmental Test of Visual Perception were used for determining concurrent validity. Within the scope of the validity study on Miller Function and Participation Scales, construct validity, its relationship with other variables, and clinical discriminant validity were demonstrated. In the reliability study, internal consistency, test-retest reliability, and inter-rater correlation coefficients were calculated. Considering the results of the study, it was concluded that the Turkish version of Miller Function and Participation Scales is a valid and reliable assessment tool for children aged 48-95 months.

Keywords: Motor Development; Miller Function and Participation Scales; Assessment

DOI: $10.24130 /$ eccd-jecs. 1967201932164

Başlıca Yazar: Hande Usbaş

* Bu çalışma ilk yazarın Marmara Üniversitesi Eğitim Bilimleri Enstitüsü’nde tamamladı̆̆ı doktora tezinden türetilmiștir.

${ }^{1}$ İstanbul Arel Üniversitesi, Sağlık Bilimleri Yüksekokulu, Çocuk Gelişimi Bölümü, handeusbas@arel.edu.tr, ORCID: https://orcid.org/0000-0002$\underline{0303-9846}$

$\frac{2}{2}$ Maltepe Üniversitesi, Eğitim Fakültesi, Temel Eğitim Bölümü, renginzembat@maltepe.edu.tr, ORCID: https://orcid.org/0000-0002-2377-8910 


\section{SUMMARY}

\section{Introduction}

Early childhood is considered as a critical period for human development, particularly for development and proficiency of motor skills. The assessment of motor development is vital to understand the typical development process, and to develop a treatment method if any unusual condition is observed in motor function. The aims of this study are to generate a Turkish translation of the Miller Function and Participation Scales, a multidimensional developmental assessment tool for assessing gross, fine and visual motor skills in children, and to carry out a validity and reliability research on this Turkish version in children aged 48-95 months.

\section{Method}

The research was designed as a quantitative research, and the study group was formed through goal-oriented sampling. The eligibility criteria were determined by the researcher and the field specialists. The study group comprised of a total of 262 children aged 48-95 months, including a special-needs education group of children. Children with typical development were selected from the population residing in Kadıköy, Üsküdar and Beykoz districts in Asian Side, and in Bakırköy district in European Side. The gross motor development test of Miller Function and Participation Scales was implemented at six schools meeting the required physical conditions. From these schools, a total of 250 children aged 48-95 months having typical development and continuing their education were included in the study group. In addition, 12 children aged 48-95 months with delayed motor development were also included in the clinical study group of Miller Function and Participation Scales. Of the 12 children with an average age of 67 months ( 5 years and 7 months), 3 children receive an individualized education in Kadıköy and 9 children in Pendik, all in Special Education and Rehabilitation Center. The study data were gathered with a personal information form created by the researcher, as well as with Miller Function and Participation Scales. Gazi Early Childhood Development Assessment Tool and Frostig Developmental Test of Visual Perception were used for determining criterion validity. Within the scope of the validity study on Miller Function and Participation Scales, construct validity, its relationship with other variables, and clinical discriminant validity were demonstrated. In the reliability study, internal consistency, test-retest reliability, and inter-rater correlation coefficients were calculated.

\section{Results}

The results of the zero-order correlation analysis of the scores obtained from motor development subtests of Miller Function and Participation Scales vary in the range of .71 to .85, thus indicating that Miller Function and Participation Scales measures a single underlying construct. In other words, each motor development test is highly significantly related to each other. The partial correlation results controlling for age variable are lower than the zero-order correlation results (.32-.46). This finding shows that the subtests (visual, fine 
and gross motor) of Miller Function and Participation Scales are both related to each other and measure different aspects of motor development. According to the criterion validity analysis results of the assessment tool, the calculated correlation coefficients between the total scores obtained by the study group in Gazi Early Childhood Development Assessment Tool and in Miller Function and Participation Scales were .74 for fine motor domain, and .94 for gross motor domain in children aged 48-71 months. As for visual motor domain, the calculated correlation coefficients between the total scores obtained by the study group in Frostig Developmental Test of Visual Perception and in Visual Motor test of Miller Function and Participation Scales was $0.94(\mathrm{p}<.01)$. The results obtained from the variance analysis of the age groupbased comparison of Miller Function and Participation Scales' Visual Motor, Fine Motor and Gross Motor raw scores shows that all motor development domains differ significantly according to age groups. The comparison of Visual Motor, Fine Motor and Gross Motor scores obtained by children with typical development and children with delayed motor development in Miller Function and Participation Scales indicates that the scores of the said children groups differ significantly in all motor development domains $(\mathrm{p}<.01)$. Internal consistency values calculated with Cronbach's alpha for all sample and age groups vary in the range of .61-.93. For all age groups, test-retest reliability scores were calculated, and all correlation coefficients were found to be in the range .71-.99. Inter-rater correlation coefficient for each motor domain was .99.

\section{Conclusion and Discussion}

The validity and reliability of Miller Function and Participation Scales were evaluated with a variety of methods. First, it was ensured that the content and theoretical structure of Miller Function and Participation Scales are consistent by carrying out an expert opinion-based content validity analysis. For construct validity, the zero-order and partial correlations of Visual Motor, Fine Motor and Gross Motor tests were examined. For criterion validity, the correlations with Gazi Early Childhood Development Assessment Tool and Frostig Developmental Test of Visual Perception were analyzed. For developmental validity, the raw scores obtained by children aged 48-95 months in Visual Motor, Fine Motor and Gross Motor tests were compared according to age groups. For clinical discriminant validity, the scores obtained by children with typical development and children with delayed motor development in all motor development tests were compared. Moreover, internal consistency (Cronbach's alpha), standard error of measurement, test-retest reliability, and inter-rater reliability were examined within the scope of reliability studies on Miller Function and Participation Scales. All validity and reliability analysis results are in compliance with the results obtained by Miller (2006) from the original analyses carried out for the scales. In the light of these results, it can be said that Miller Function and Participation Scales will allow pedagogues, child development specialists, physiotherapists, and occupational therapists to assess the development of gross, fine and visual motor skills of children aged 48-95 months with typical development or special needs in a systematic and multidimensional way, as well as to develop the necessary education, treatment and therapy goals. 


\section{GİRIŞ}

Motor gelişim, gelişimin kalbidir. Özellikle motor becerilerin yeterlilik ve gelişimi için kritik bir dönem olan bebeklik ve erken çocukluk döneminde alg1, planlama ve motivasyon da dahil olmak üzere, gelişimin tüm farklı yönlerini yansıtan birincil göstergesidir (Draper, Achmat, Forbes ve Lambert, 2012, s. 137; Lam, 2011, s. 189). Motor davranışlardaki yaşam boyu süren değişimler ve bu değişimlerin altında yatan süreçler olarak tanımlanan ve motor gelişimin en üst eylemi olan hareket, çocukların erken öğrenme becerilerini desteklemektedir. Hareket becerisini gerçekleştirme eylemi olarak ifade edilen motor performans ise doğrudan gözlemlenebilir ve çıktısı herhangi bir nicelik ile ölçülebilir (Payne ve Isaacs, 2012; Gallahue, Ozmun ve Goodway, 2014; Haywood, Roberton ve Getchell, 2012; Lam, 2011). Çocukların motor performans becerilerinin değerlendirilmesi, çevresel, kişisel ve bağlamsal faktörlerden etkilenen giyinme, kişisel bakım gibi okul, ev ve toplum ortamlarında katılımı desteklemede temel olan günlük yaşam aktivitelerini gerçekleştirirken kullandıkları işlevleri yansıtmalıdır. Bu nedenle, çocukların günlük yaşamlarında kullandıkları doğal görevleri içeren bir değerlendirme, çocuğun fonksiyonel beceri derecesinin doğru değerlendirilmesinde önemlidir (James, Ziviani ve Boyd, 2014; Park, 2017).

Değerlendirme, çocuk ve çevresi hakkındaki bilgilerin sistematik bir şekilde toplanması ve birçok amaç için kullanılabilecek olan resmin bütünündeki çeşitli parçaların entegrasyonudur (Burton ve Miller 1998; akt. Sugden ve Wade, 2013). Çocuğun motor beceri gerektiren günlük aktivitelerini bağımsız ve güvenli olarak yapabilme yeteneği olarak tanımlanan motor fonksiyonun değerlendirilmesi, normal gelişim sürecinin anlaşılmasında ve motor fonksiyonun olağan dış1 olduğu durumların belirlenmesi yoluyla eğitim ve tedavi amaçlarının oluşturulmasında hayati öneme sahiptir. Aynı zamanda, motor problemlerin erken tespiti ve müdahale programlarının başlatılması birçok fiziksel ve ilgili duygusal problemleri ortadan kaldırır veya minimize eder. Ayrıca, temel motor becerilerin değerlendirilmesi, çocuklanın bir ya da daha fazla temel motor becerideki yeterliliğe dayanan performansı, spor gibi daha yapılandırılmış faaliyetlere katılımı için hazır bulunuşluğunun bir göstergesi olabilir. Her yaşta ve tüm yetenek düzeylerinde hareket becerilerinin en uygun şekilde öğretilmesine/geliştirilmesine olanak tanıyan gelişimsel olarak uygun aktivitelerin düzenlenmesini sağlar (Erdoğanoğlu ve Kerem Günel, 2007; Jurimae ve Jurimae, 2001; Payne ve Isaacs, 2012).

Burton ve Miller (1998) ise değerlendirmenin birçok farklı amaç için kullanabileceğini ifade eder ve şu şekilde sıralarlar: (i) Çocuğu uygun özel eğitim hizmetlerine yönlendirebilmek için tanılamak ve sınıflandırmak, (ii) çocuğa yönelik erken müdahale programları tasarlamak, (iii) süreç içerisinde 
gerçekleşen değişimleri belirlemek için çocuğun gelişimini incelemek, (iv) işbirliği içinde olunan diğer kişilere geri bildirim vermek, (v) uygulanan belirli bir müdahale modelinin etkililiğini sınamak ve (vi) çocuğun içinde bulunduğu ortam özelliklerine genel bir bakış sağlamak (akt. Sugden ve Wade, 2013, s. 337). Bu nedenlerle, erken çocukluk döneminde, çocukların motor gelişimlerini anlamak ve uygun planlamalar yapabilmek amacıyla motor gelişimin değerlendirilmesi önemli ve gerekli olarak kabul edilmektedir (Lam, 2011, s. 189).

Erken çocukluk döneminde motor gelişimi değerlendirmek için uygulama prosedürü, değerlendirme yaklaşımı (ürün ya da süreç odaklı) ve değerlendirdiği motor alanı (kaba, ince ve görsel motor) farklılık gösteren yurt dişı (Bruininks-Oseretsky Motor Proficiency Test, Test of Gross Motor Development, Beery-Buktenica Developmental Test of Visual-Motor Integration, Miller Function and Participation Scales) ve yurt içinde (Gazi Erken Çocukluk Değerlendirme Aracı, Ankara Gelişim Tarama Envanteri v.b.) geliştirilmiş farklı motor gelişim ölçme araçları bulunmaktadır. Ülkemizde geliştirilen ya da farklı dillerden uyarlaması yapılan motor gelişim ölçekleri incelendiğinde, kaba, ince ve görsel motor bütünleşmesine ve altta yatan nörolojik profilin değerlendirilmesine odaklanan, çocukların günlük yaşamlarında kullandıkları doğal görevleri içeren performans becerilerini temel alan bir değerlendirme aracı ihtiyaç olarak görülmektedir.

$\mathrm{Bu}$ durumdan yola çıkılarak, çocukların motor gelişimlerini değerlendirmek amacıyla iş ve uğraş1 terapisti Lucy Jane Miller tarafindan 2006 yılında, fizik tedavi uzmanları, iş ve uğraşı terapistleri ve erken çocukluk uzmanlarının kullanımı için geliştirilmiş olan Miller Fonksiyon ve Katılım Ölçeği (Miller Function \& Participation Scales: M-FUN)'nin Türkçe formunun 48-95 ay arası çocukların görsel, ince ve kaba motor gelişimlerini değerlendirmeye yönelik olarak geçerlik ve güvenirlik çalışmasının yapılması araştırmanın amacını oluşturmaktadır.

Miller Fonksiyon ve Katılım Ölçeği, okul ve günlük ev işlerindeki görevlerde başarılı olmak için gerekli bütünleşik becerilere yönelik olarak hem tipik gelişim gösteren hem de özel gereksinimli çocukların kaba, ince ve görsel motor yeterliklerinin sistematik ve çok boyutlu değerlendirilmesinde kullanılmaktadır. Okul öncesi ve ilkokul döneminin ilk yıllarındaki çocukların motor fonksiyonun her bir alanında bireysel değerlendirme yapılabilmesi için eğlenceli oyun ve aktiviteler kullanılarak tasarlanmıştır. Miller Fonksiyon ve Katılım Ölçeği'nde, American Occupational Therapy Association (AOTA) tarafindan belirlenen İş Uğraşı Terapisi Uygulama Çerçevesi’nde yer alan üç tip performans becerisi temel alınmıştır. Ölçekte yer alan görsel, ince ve kaba motor performans becerileri, devinim, stabilite, güç, dayanıklılık, duruş fonksiyonları, koordinasyon ve faaliyetlerin manipülasyon bileşenlerini içermektedir. Süreç becerileri, organizasyon, uyum, dikkat, sürekli çaba 
ve bir aktivitenin nasıl tamamlanacağına dair bilgiyi kapsamaktadır. İletişim becerileri ise, beden ve yüz tarafından sağlanan sözel olmayan mesajlar, sözel iletişim ve kişilerarası ilişkiler dâhil olmak üzere ihtiyaçları veya niyetleri iletmek için gereken sosyal davranışlarından oluşmaktadır (Miller, 2006).

Yukarıda elen alınan bilgiler doğrultusunda, Miller Fonksiyon ve Katılım Ölçeği (Miller Function \& Participation Scales: M-FUN)'nin Türkçe formunun geçerlik ve güvenirlik çalışmasının yapılması,

- Türkiye' de erken çocukluk dönemine yönelik kaba, ince ve görsel motor bütünleşmenin değerlendirilmesine odaklanan ölçeklerin sınırlı olması açısından,

- Çocukların motor gelişiminin kaba, ince ve görsel motor olmak üzere her üç alanda da incelenebilmesi ve ilgili nörolojik alanlara yönelik bir profil ortaya çıkarılması açısından,

- Erken eğitim düzenlemeleri ve ilkokula başarılı katılım sağlayabilmesi için bir çocuğun performans becerilerinin ölçülmesi açısından,

- Eğitimcilerin, çocuk gelişimi uzmanlarının, fizyoterapistlerin ve iş-uğraşı terapistlerinin hem tipik gelişim gösteren hem de özel gereksinimli çocukları daha sistematik ve çok boyutlu değerlendirebilmelerine olanak sağlayan; gelişimsel gereklilikleri erken tespit edebilecekleri; motor gecikme derecesi ve alanlarını belirleyebilecekleri; zamanla ilerlemeyi izlemek için bir sonuç ölçütü olarak kullanabilecekleri; çocukların güçlü ve zayıf yönlerinin tespit edilmesi ile zayıf yönlerine yönelik kolaylıkla eğitim, tedavi ve terapi amaçları geliştirebilecekleri bir araç sağlaması açısından önem taşımaktadır.

\section{YÖNTEM}

Bu bölümde, araştırma modeli, çalışma grubu, veri toplama araçları, verilerin toplanması ve verilerin analizinde kullanılan istatistiksel işlem ve tekniklere yer verilmiştir.

\section{Araştırmanın Modeli}

Araştırma nicel araştırma türünde tasarlanmış ve tarama modellerinden ilişkisel tarama modeli kullanılmıştır. Tarama modelleri geçmişte ya da halen var olan bir durumu var olduğu şekli ile betimlemeyi amaç edinen araştırmalar için uygun bir modeldir. İlişkisel tarama modelleri, iki veya daha çok değişken arasında birlikte değişim varlığını ve/veya derecesini belirlemeyi amaçlayan araştırma modelleridir (Karasar, 2006). Araştırmada Miller Fonksiyon ve Katılım Ölçeği’nin Türkçe formunun geçerlik ve güvenirlik analizleri yapılmıştır. 


\section{Çalışma Grubu}

Araştırmanın çalışma grubu, amaca yönelik örnekleme yoluyla oluşturulmuştur. Amaca yönelik örnekleme deseninin ayırıcı özelliği, seçilecek bireyler için belirli ölçütlerin araştırma öncesinde tanımlanmış olmasıdır (Gliner, Morgan ve Leech, 2015, s. 124). Araştırmanın çalışma grubunu 4895 ay arası özel eğitim grubu dâhil olmak üzere toplam 262 çocuk oluşturmaktadır. Tipik gelişim gösteren çalışma grubu için, İstanbul İli Anadolu yakasında Üsküdar, Kadıköy, Beykoz ilçeleri; Avrupa yakasında ise Bakırköy ilçesi kolay ulaşılabilirlik ilkesi göz önüne alınarak seçilmiştir. Belirlenen ilçelerdeki okulları uygulama sürecine dâhil edilebilmek için Miller Fonksiyon ve Katılım Ölçeği’nin kaba motor alanında yer alan maddelerin değerlendirilebilmesine yönelik uygun düzenlemeler yapabilmek için gerekli fiziksel koşullara sahip olma ölçütü aranmıştır. İlçe Milli Eğitim Müdürlükleri'ne bağlı altı devlet ilkokul ve anaokulunun gerekli ölçütleri sağladığ1 tespit edilmiştir. Seçilen altı okulda eğitim öğretime devam eden ve tipik gelişim gösteren (Rehberlik Araştırma Merkezi tarafindan herhangi bir tanı almamış) 48-95 ay arası toplam 250 çocuk araştırmanın çalışma grubuna dâhil edilmiştir. Çocukların ebeveynlerinin doldurdukları kişisel bilgi formlarından edinilen bilgiye göre çocukların hepsi orta sosyo-ekonomik düzeydeki ailelerden gelmektedir.

Miller Fonksiyon ve Katılım Ölçeği’nin klinik grupları ayırt etme geçerliğini araştırmak için özel eğitim tanısı almış ve motor gelişim alanının görsel, ince ve kaba motor alanlarının bir ya da daha fazlasında gecikme yaşanan 48-95 ay aras1 12 çocuk ebeveynlerinden izin alınarak çalışmaya dâhil edilmiştir. Yaş ortalaması 67 ay (5 yaş 7 ay) olan 12 çocuğun 3'ü Kadıköy ilçesinde, 9’u Pendik ilçesinde olmak üzere tamamı Özel Eğitim ve Rehabilitasyon Merkezi'nde bireysel eğitim almaktadır. Aynı zamanda 6 çocuk okul öncesi eğitim sınıfına, 1 çocuk ilkokul birinci sınıfa kaynaştırma öğrencisi olarak devam etmektedir. 1 çocuk ilkokul bünyesinde özel eğitim alt sınıfinda öğrenim görmektedir. 9 çocuk ise “Aktifim Toplumun İçindeyim Projesi” kapsamında Bütünleşik Fiziksel Aktivite Merkezine devam etmektedir.

Tipik gelişim gösteren çocuklara ilişkin demografik özelliklerini tanımlayıcı frekans ve yüzde değerleri Tablo 1'de sunulmuştur.

Tablo 1. Tipik gelişim gösteren çocuklara ilişkin demografik özellikler

\begin{tabular}{llcc}
\hline Demografik Bilgiler & & $\boldsymbol{f}$ & $\%$ \\
\hline Cinsiyet & Kız & 119 & 47,6 \\
& Erkek & 131 & 52,4 \\
\hline Kronolojik Yaş & $48-53$ ay & 54 & 21,6 \\
& $54-59$ ay & 43 & 17,2 \\
& $60-71$ ay & 53 & 21,2 \\
\hline
\end{tabular}




\begin{tabular}{|c|c|c|c|}
\hline & $72-83$ ay & 46 & 18,4 \\
\hline & 84-95 ay & 54 & 21,6 \\
\hline \multirow[t]{3}{*}{ Anne Yaş1 } & $20-29$ & 26 & 10,4 \\
\hline & $30-40$ & 164 & 65,6 \\
\hline & 41 ve üstü & 60 & 24,0 \\
\hline \multirow[t]{3}{*}{ Baba Yaşı } & $20-29$ & 6 & 2,4 \\
\hline & $30-40$ & 130 & 52,0 \\
\hline & 41 ve üstü & 114 & 45,6 \\
\hline \multirow[t]{7}{*}{ Anne Öğrenim Durumu } & Okuryazar değil & 1 & 0,4 \\
\hline & İlkokul mezunu & 15 & 6,0 \\
\hline & Ortaokul mezunu & 26 & 10,4 \\
\hline & Lise mezunu & 87 & 34,8 \\
\hline & Ön lisans mezunu & 5 & 41,6 \\
\hline & Üniversite mezunu & 104 & 4,8 \\
\hline & Lisansüstü mezunu & 12 & 2,0 \\
\hline \multirow[t]{6}{*}{ Baba Öğrenim Durumu } & İlkokul mezunu & 17 & 6,8 \\
\hline & Ortaokul mezunu & 15 & 6,0 \\
\hline & Lise mezunu & 93 & 37,2 \\
\hline & Ön lisans mezunu & 5 & 1,2 \\
\hline & Üniversite mezunu & 104 & 41,6 \\
\hline & Lisansüstü mezunu & 18 & 7,2 \\
\hline \multirow[t]{2}{*}{ Anne Çalışma Durumu } & Çalışıyor & 125 & 50,0 \\
\hline & Çalışmıyor & 125 & 50,0 \\
\hline \multirow[t]{2}{*}{ Baba Çalışma Durumu } & Çalışıyor & 238 & 95,2 \\
\hline & Çalışmıyor & 12 & 4,8 \\
\hline \multirow[t]{2}{*}{ Kardeşi Olma Durumu } & Kardeşi var & 96 & 38,4 \\
\hline & Kardeşi yok & 154 & 61,6 \\
\hline \multirow[t]{3}{*}{ Devam Ettiği Sınıf Düzeyi } & Okul öncesi & 171 & 68,4 \\
\hline & Birinci Sinıf & 53 & 21,2 \\
\hline & İkinci Sınıf & 26 & 10,4 \\
\hline Toplam & & 250 & 100 \\
\hline
\end{tabular}

Tablo 1'e göre göre araştırmanın çalışma grubundaki tipik gelişim gösteren 48-95 ay arası 250 çocuktan; 119'u kız ve 131'i erkektir. Bu çocukların 54'ü 48-53 aylık, 43'ü 54-59 aylık, 53’ü 60-71 aylık, 46'sı 72-83 aylık ve 54’ü 84-95 aylıktır. Çocukların annelerinin yaşı incelendiğinde, anne yaş1 20-29 yaş arası olan 26, 30-40 yaş arası olan 164, 41 ve üstü yaş olan 60 çocuk olduğu görülmektedir. Çocukların babalarının yaşları incelendiğinde ise, baba yaşı 20-29 yaş arası olan 6, 30-40 yaş arası olan 130, 41 ve üstü yaş olan 114 çocuk bulunmaktadır. Çocukların annelerinin öğrenim durumu incelendiğinde, annesi okuryazar olmayan 1, ilkokul mezunu 15, ortaokul mezunu 26, lise mezunu 87, ön lisans mezunu 5, üniversite mezunu 104 ve lisansüstü mezunu 12 çocuk olduğu görülmektedir. Çocukların babalarının öğrenim durumu incelendiğinde ise, babası ilkokul mezunu 17, ortaokul mezunu 15, lise mezunu 93, ön lisans mezunu 5, üniversite mezunu 104 ve lisansüstü mezunu 18 çocuk bulunmaktadır. Çocukların annelerinin çalışma durumu incelendiğinde, 125 çocuğun annesinin çalışmakta, 125 çocuğun annesinin ise çalışmamakta olduğu görülmektedir. Çocukların babalarının çalışma durumu incelendiğinde ise, 238 çocuğun babasının çalışmakta, 12 çocuğun babasının çalışmamakta olduğu görülmektedir. Çocukların kardeşi olma durumu incelendiğinde, 96 çocuğun kardeşi olduğu, 154 çocuğun kardeşi olmadığı görülmektedir. 
Çocukların devam ettiği sınıf düzeyine bakıldığında, 171 çocuğun okul öncesi eğitim sınıfına, 53 çocuğun birinci sınıfa ve 26 çocuğun ikinci sınıfa devam ettiği görülmektedir.

Miller Fonksiyon ve Katılım Ölçeği'nin klinik ayırt edici geçerliğini araştırmak için uygulama yapılan özel eğitim tanısı almış ve motor gelişim gecikmesi olan çocuklara ilişkin demografik özelliklerin tanımlayıcı frekans ve yüzde değerleri Tablo 2'de sunulmuştur.

Tablo 2. Özel eğitim tanısı almış ve motor gelişim gecikmesi gösteren çocuklara ilişkin demografik özellikler

\begin{tabular}{|c|c|c|c|}
\hline Demografik Bilgiler & & $f$ & $\%$ \\
\hline \multirow[t]{2}{*}{ Cinsiyet } & $\mathrm{K}_{12}$ & 3 & 25,00 \\
\hline & Erkek & 9 & 75,00 \\
\hline \multirow[t]{5}{*}{ Kronolojik Yaş } & $48-53$ ay & 2 & 16,6 \\
\hline & 54-59 ay & 2 & 16,6 \\
\hline & $60-71$ ay & 4 & 33,6 \\
\hline & $72-83$ ay & 2 & 16,6 \\
\hline & $84-95$ ay & 2 & 16,6 \\
\hline \multirow[t]{4}{*}{ Tanı Grubu } & Zihinsel Gelişim & 2 & 16,6 \\
\hline & Yetersizliği & & \\
\hline & Otizm & 9 & 75,0 \\
\hline & DEHB & 1 & 8,4 \\
\hline \multirow[t]{3}{*}{ Anne Yaşı } & $20-29$ & 2 & 16,7 \\
\hline & $30-40$ & 5 & 41,7 \\
\hline & 41 ve üstü & 5 & 41,7 \\
\hline \multirow{3}{*}{ Baba Yaşı } & $20-29$ & 1 & 8,3 \\
\hline & $30-40$ & 5 & 41,7 \\
\hline & 41 ve üstü & 6 & 50,0 \\
\hline \multirow[t]{5}{*}{ Anne Öğrenim Durumu } & Okuryazar değil & 1 & 8,3 \\
\hline & İlkokul mezunu & 3 & 25,0 \\
\hline & Ortaokul mezunu & 1 & 8,3 \\
\hline & Lise mezunu & 4 & 33,3 \\
\hline & Üniversite mezunu & 3 & 25,0 \\
\hline \multirow[t]{3}{*}{ Baba Öğrenim Durumu } & İlkokul mezunu & 3 & 25,0 \\
\hline & Lise mezunu & 5 & 41,7 \\
\hline & Üniversite mezunu & 4 & 33,3 \\
\hline \multirow[t]{2}{*}{ Anne Çalışma Durumu } & Çalışıyor & 2 & 16,7 \\
\hline & Çalışmiyor & 10 & 83,3 \\
\hline \multirow[t]{2}{*}{ Baba Çalışma Durumu } & Çalışıyor & 11 & 91,7 \\
\hline & Çalışmiyor & 1 & 8,3 \\
\hline \multirow[t]{2}{*}{ Kardeşi Olma Durumu } & Kardeşi var & 5 & 41,7 \\
\hline & Kardeşi yok & 7 & 58,3 \\
\hline \multirow[t]{4}{*}{ Devam Ettiği Sınıf Düzeyi } & Okul öncesi & 6 & 50,0 \\
\hline & Birinci sinıf & 1 & 8,3 \\
\hline & Özel eğitim alt sinıfi & 1 & 8,3 \\
\hline & Okula gitmiyor & 4 & 33,4 \\
\hline Toplam & & 12 & 100 \\
\hline
\end{tabular}

Tablo 2'ye göre göre araştırmanın çalışma grubundaki özel eğitim tanısı almış ve motor gelişim gecikmesi gösteren 48-95 ay arası 12 çocuktan; 3'ü kız ve 9'u erkektir. Bu çocukların 2'si 48-53 aylık, 2'si 54-59 aylık, 4'ü 60-71 aylık, 2'si 72-83 aylık ve 2'si 84-95 aylıktır. 2 çocuk zihinsel gelişim yetersizliği, 9 çocuk otizm ve 1 çocuk dikkat eksikliği hiperaktivite bozukluğu tanısı almıştır. Çocukların annelerinin yaşı incelendiğinde, anne yaşı 20-29 yaş arası olan 2, 30-40 yaş arası olan 5, 41 ve üstü yaş olan 5 çocuk olduğu görülmektedir. Çocukların babalarının yaşları incelendiğinde 
ise, baba yaşı 20-29 yaş arası olan 1, 30-40 yaş arası olan 5, 41 ve üstü yaş olan 6 çocuk bulunmaktadır. Çocukların annelerinin öğrenim durumu incelendiğinde, annesi okuryazar olmayan 1, ilkokul mezunu 3, ortaokul mezunu 1, lise mezunu 4 ve üniversite mezunu 3 çocuk olduğu görülmektedir. Çocukların babalarının öğrenim durumu incelendiğinde ise, babası ilkokul mezunu 3, lise mezunu 5 ve üniversite mezunu 4 çocuk bulunmaktadır. Çocukların annelerinin çalışma durumu incelendiğinde, 2 çocuğun annesinin çalışmakta, 10 çocuğun annesinin ise çalışmadığ1 görülmektedir. Çocukların babalarının çalışma durumu incelendiğinde ise, 11 çocuğun babasının çalışmakta, 1 çocuğun babasının ise çalışmamakta olduğu görülmektedir. Çocukların kardeşi olma durumu incelendiğinde, 5 çocuğun kardeşi olduğu, 7 çocuğun kardeşi olmadığ görülmektedir. Çocukların devam ettiği sınıf düzeyine bakıldığında, 6 çocuğun okul öncesi eğitim sınıfına, 1 çocuğun birinci sınıfa, 1 çocuğun özel eğitim sınıfina devam ettiği ve 4 çocuğun okula gitmediği görülmektedir.

\section{Veri Toplama Araçları}

Bu araştırmada 48-95 ay arası çocuklar ve ailelerine ait bilgiler araştırmacı tarafından oluşturulan "Kişisel Bilgi Formu” kullanılarak elde edilmiştir. Çocukların motor gelişim düzeylerini belirleyebilmek için "Miller Fonksiyon ve Katılım Ölçeği (M-FUN)" kullanılmıştır. Gazi Erken Çocukluk Gelişimi Değerlendirme Aracı (GEÇDA) ve Frostig Gelişimsel Görsel Alg1 Testi (DTVP) Miller Fonksiyon ve Katılım Ölçeği'nin uyum geçerliği için kullanılmıştır.

\section{Kişisel Bilgi Formu}

Kişisel Bilgi Formu, çalışma grubundaki 48-95 ay arası çocuklar ve ailelerine ait demografik özelliklerin belirlenmesi amacıyla araştırmacı tarafından hazırlanmıştır. İlgili form, anne-baba yaş, öğrenim ve çalışma durumu ile çocukların cinsiyet, kronolojik yaş, kardeşi olma durumu, okul öncesi eğitim alma süresinin belirlenmesinde kullanılmıştır. Kişisel Bilgi Formu sınıf öğretmenleri tarafından ailelere ulaştırılmış ve çocukların ebeveynleri tarafindan doldurulmuştur.

\section{Miller Fonksiyon ve Katılım Ölçeği (Miller Function \& Participation Scales: M-FUN) ve Uyarlama Süreci}

Miller Fonksiyon ve Katılım Ölçeği (Miller Function \& Participation Scales: M-FUN) 30-95 ay arasındaki çocukların motor gelişimlerini değerlendirmek amacıyla iş ve uğraşı terapisti Lucy Jane Miller tarafindan 2006 yllında, fizik tedavi uzmanları, iş ve uğraşı terapistleri ve erken çocukluk uzmanlarının kullanımı için geliştirilmiştir. Miller Fonksiyon ve Katılım Ölçeği bu yaş grubu hem 
tipik gelişim gösteren hem de özel gereksinimli çocukların kaba, ince ve görsel motor bütünleşmesinin sistematik ve çok boyutlu değerlendirilmesine imkân tanır. Miller Fonksiyon ve Katılım Ölçeği eğlenceli oyun ve aktiviteler kullanılarak motor fonksiyonun her bir alanında bireysel değerlendirme yapılabilmesi için tasarlanmıştır. Değerlendirme, okul öncesi ve ilkokul döneminin ilk yıllarındaki çocukların günlük yaşamlarındaki fonksiyonel aktivitelerini kapsamaktadır. Miller Fonksiyon ve Katılım Ölçeği okul ve günlük ev işlerindeki görevlerde başarılı olmak için gerekli bütünleşik beceriler için öğrencilerin yeterliklerinin değerlendirilmesinde kullanılmaktadır. Miller Fonksiyon ve Katılım Ölçeği yoluyla değerlendirilen performans becerileri erken okul başarısı için önde gelen görevler ile büyük ölçüde ilgilidir (Miller, 2006). Doğal bağlamlarda fonksiyonel motor becerilerin değerlendirmesinde kullanıldığı gibi, zamanla ilerlemeyi izlemek için bir sonuç ölçütü olarak da kullanılabilir. Motor gecikme derecesi ve alanlarının belirlenmesine ek olarak, tedavi müdahalesi ve amaçlarının geliştirilmesinde yardımcı olur (Miller, 2006; akt. Diemand, 2009, s.16). Ayrıca, çocuğun alt testleri anlamasına yardımcı olmak için değerlendiricinin işaret dilini/jestleri kullanmasına imkân vermesi, dil işleme sorunu olan çocuklar için daha geçerli bir değerlendirme imkânı sunmaktadır. Aynı zamanda, motor gelişim alanları ile ilişkili nörolojik bir profil ortaya koymaktadır. Miller Fonksiyon ve Katılım Ölçeği'nde değerlendirilen Nörolojik Temeller dört alanda kategorize edilmiştir: El Fonksiyonu, Motorsuz Görsel Alg1lama, Postüral Beceriler, Yürütücü Fonksiyon ve Katılım. Bu dört alanda tanımlanan ve performans aktivitelerinde test edilen yetenekler Tablo 3'de verilmiştir (Miller, 2006, s.5).

Tablo 3. Miller Fonksiyon ve Katılım Ölçeği performans aktivitelerinde test edilen yetenekler

\begin{tabular}{ll}
\hline El Fonksiyonu & Postüral (Duruşla ilişkili) Beceriler \\
\hline Orta hattı çaprazlama & Baskın olmayan el ile kendiliğinden yardım \\
El kuvveti & Çift yönlü koordinasyon \\
Nesneyi el içinde manipüle etme & Tek yönlü koordinasyon \\
Kavrama olgunluğu & Denge ve kararlılık \\
Parmaklarla kavrama & Beden farkındalı̆̆1 \\
Motor doğruluk & Dayanıklılık \\
Motor planlama & Motor planlama \\
Bırakma & Motor doğruluk \\
& Sabitlik \\
& Kuvvet \\
\hline Yürütücü Fonksiyon ve Katılım & Ağırlık aktarımı \\
\hline Detaylara dikkat etme & Motorsuz Görsel Algılama \\
Planlama & Figür-zemin \\
Öz-denetim & Görsel ayırt etme \\
Paylaşım/sırayla yapma & Görsel tarama/uzun süreli dikkat \\
Sosyal uyum & \\
\hline
\end{tabular}

Testin performans bileşeni norm referanslıdır. Performans değerlendirmesi, 48-71 ay çocuklar için 15 aktivite; 72- 95 ay arası çocuklar için 16 aktivite içermektedir ve toplam 67 test maddesinden 
oluşmaktadır. Katılım bileşeni ise kriter referanslıdır. Uygulamalar çocuklarla birebir yapılmakta ve yaklaşık her çocuk için 40-60 dakika sürmektedir. Testin üç alanı (görsel, ince ve kaba motor) bağımsız olarak uygulanabilir ya da tek bir oturumda üç alanın uygulaması gerçekleştirilebilir. Uygulama ortamı sakin, dikkat dağıtıcı olmayan, yeterli aydınlatmaya sahip, halı ya da masif yüzeyde ve tüm aktiviteler için uygun bir oda olmalıdır. Çocuklar iyi bir ayakkabı giymeli ya da yalınayak olmalıdır. Odada, çocuk boyutunda bir masa ve iki sandalye bulunmalıdır. Testin materyalleri şunlardır:

- Kontrolör kilavuzu

- Uygulama yönergeleri kitab1

- Kayıt formları (30 - 47 ay ve 48 - 95 ay olmak üzere iki farklı form) Kayıt Formu, Test Gözlemleri Kontrol Listesi ve Nörolojik Temeller Profilini içerir.

- Alıştırma kitapları (Her 2 yaş grubu için)

- Ev gözlemleri kontrol listesi

- Okul gözlemleri kontrol listesi

- Değerlendirme için gerekli nesneler ve oyuncaklar

Ölçeğin Türkçe formunun geçerlik güvenirlik çalışmasının yapılması ve kullanımı için yasal sahibi ile iletişim kurulmuş ve lisans anlaşması imzalanmıştır. Kullanım izninde belirtilen süre içerisinde uygulamalar tamamlanmıştır. Araştırmada, süre sınırlıllğı nedeniyle ölçeğin sadece görsel, kaba ve ince motor aktiviteleri kullanılarak performans değerlendirmesi yapılmış; ev ve okul kontrol listeleri uyarlamaya dâhil edilmemiştir. Performans değerlendirmesi ve kontrol listeleri değerlendirme için ayrı ayrı kullanılabilmektedir. Fakat öğrencinin evde veya sınıfta gösterdiği performans hakkında arka plan bilgisi sağlaması açısından ileriki çalışmalarda kontrol listelerinin Türkçe formlarının geçerlik güvenirlik çalışmalarının yapılması çocuğun kapsamlı şekilde değerlendirilebilmesi açısından faydalı olacaktır.

Uyarlama çalışmaları için öncelikle ölçeğin kullanma kılavuzu, değerlendirme tabloları ve kişisel kayıt formunun İngilizce orijinali akademik olarak iyi derecede İngilizce bilen Çocuk Gelişimi, Beden Eğitimi ile Fizyoterapi ve Rehabilitasyon alanlarında bir uzmana verilerek Türkçe’ ye çevirisi yapılmıştır. Çeviri metin Türkçe dil uzmanları tarafindan incelenmiş ve gerekli düzenlemeler yapıldıktan sonra Mütercim-Tercümanlık Bölümü iki öğretim üyesi tarafindan orijinal metinle karşılaştırılmıştır. İki çeviri arasında Miller Fonksiyon ve Katıllım Ölçeği'nin güvenirliğini düşürebilecek bir farklılaşma gözlenmemiştir. 
İçerik geçerliği için, Çocuk Gelişimi, Fizyoterapi ve Rehabilitasyon, Beden Eğitimi ve Spor, Sınıf Öğretmenliği alanında farklı üniversitelerde çalışmakta olan doktora derecesine sahip öğretim üyelerine ölçeğin uygulama yönergeleri ve kayıt formunun orijinali ve çevirisi gönderilerek, testin içeriğinin uygulama grubu ve teorik alan ile olan uyumuna dair geri bildirim istenmiştir. Uzmanlardan gelen görüşler doğrultusunda gerekli uyarlamalar yapılmış; fakat ölçeğin orijinalinde yer alan görsel, kaba ve ince motor alanlarındaki aktivitelerde ve madde sayılarında değişiklik yapılmamışır. İnce Motor "Kumbara Oyunu” alt testinde 10 adet sent yerine aynı boyutta olan 10 adet 10 kuruş kullanılmıştır. Kaba Motor oyunlarında ölçeğin orijinalinde inç birimi ile verilen uzunluk ölçüleri 1 inç 2,54 cm olacak şekilde metre birimi ile değiştirilerek uygulama alanının düzenlemesi yapılmıştır. Görsel Motor "Yazma Oyunu” alt testindeki Türkçe alfabede yer almayan $\mathrm{X}$ ve W harfleri, ölçeğin Kılavuz Kitabında "Yazma Oyunu” alt testindeki maddelerin amacını açıklayan bölüm temel alınarak, Türkçe alfabedeki V ve M harfleri ile değiştirilmiştir. İlkokulun 1. sınıfının ilk dönemini bitirmiş olan çocuklara uygulanan kelimeleri kopyalamaya ilişkin Madde 13, 14, 15 ve cümle kopyalamaya ilişkin Madde 16'nın Türkçe' ye uyarlanması için biri sınıf öğretmenliği alanında doktora tez çalışmasına devam eden ve on yıldan daha fazla mesleki deneyimleri olan iki sınıf öğretmeninden görüş alınmıştır. Testin bu maddelerinde, çocukların form olarak gördügüünü kopyalayabilmesi önemli olduğu için İngilizce kelimeler ve cümle Türkçe 'ye anlam karş1lı̆̆1 ile değil; ilkokul birinci sınıf okuma-yazmaya yönelik müfredat içeriğine uygun şekilde çocukların ilk öğrendikleri harfler ve kelime yapıları temel alınarak yazılış yapısı olarak benzer kelimelerle değiştirilmiştir. Görsel Motor "Yazma Oyunu” alt testinde çocuğun yazma süresi önemli olduğu için Madde 16'daki cümlede yer alan harf sayısı dikkate alınarak aynı harf sayısında Türkçe bir cümle oluşturulmuştur. Aynı şekilde Madde 13, 14 ve 15'de yer alan üç harfli kelimeler yine üç harfli Türkçe kelimelerle değiştirilmiştir. Yazma sayfalarında yer alan kelimeleri ve cümleyi betimleyen görseller, Türkçe kelimelere ve cümleye uygun görseller kullanılarak revize edilmiştir. Alan uzmanlarından gelen geri bildirimler göz önünde bulundurularak Türkçe Kayıt Formu ile Uygulama Yönergeleri kitabının son hali oluşturulmuştur. Ölçeğin Türkçe formunun 15 çocukla pilot uygulaması yapılmıştır. Pilot uygulamalarda, çocuklar tarafindan yönergelerin anlaşılırllğı ve uygulama sırasında yaşanabilecek olası durumlar değerlendirilerek kaydedilmiş ve gerekli düzenlemeler yapılmıştır.

\section{Gazi Erken Çocukluk Gelişimi Değerlendirme Aracı (GEÇDA)}

Gazi Erken Çocukluk Gelişimi Değerlendirme Aracı (GEÇDA) 0-72 ay çocukların gelişimlerinin izlenmesi, değerlendirilmesi, eğitim yaşantılarının düzenlenmesinde ve çocuklardaki gelişimsel geriliklerin erken tanılanmasında kullanılabilecek bir değerlendirme aracıdır. Aracın geliştirilme 
süreci, 1993-1994 akademik yllında başlamıştır. Uygulama formu, Devlet İstatistik Enstitüsü tarafından ağıllıklı küme örnekleme yöntemiyle belirlenen Ankara ili merkez ilçelerine bağlı farklı sosyo- ekonomik koşullardaki yerleşim birimlerinden her bir ay grubunda yaklaşık 30 çocuk ulaşmak üzere toplam 1890 çocuğa uygulanmıştır. Elde edilen veriler ile testin geçerlik ve güvenirlik analizleri yapılmıştır. 1997 yılında araç tekrar revize edilerek toplam 4242 çocuğa uygulanmış ve elde edilen verilerle Türkiye örnekleminin norm çalışması yapılımıştır.

Gazi Erken Çocukluk Gelişimi Değerlendirme Aracı (GEÇDA); Psikomotor Gelişim (PMG), Bilişsel Gelişim (BG), Dil Gelişimi (DG) ve Sosyal-Duygusal Gelişim (SDG) olmak üzere dört alt testten oluşmaktadır. GEÇDA 73'ü psikomotor gelişim, 60'ı bilişsel gelişim, 60'ı dil gelişimi ve 56's1 sosyal-duygusal gelişim alanına ait olmak üzere toplam 249 maddeden oluşmaktadır. Aracın madde sayılarında, gelişimin belirli dönemlerde farklı hızlara sahip olması nedeniyle aylara ve gelişim alanlarına göre farklılıklar bulunmaktadır. Araç, uygun bir ortamda oluşturulan gelişimsel oyunlar esnasında çocuğun gözlenmesi yoluyla uygulanmakta ve değerlendirilmektedir. Uygulama sırasında gözlenmesi mümkün olmayan maddeler ise çocuğun anne, baba veya beraber olduğu yakınına sorularak değerlendirilmektedir. Araçta bu maddeler (A) harfi ile gösterilmektedir. Çocuk, uygulanan maddeyi başarıyorsa " 1 ", başaramıyorsa " 0 " puan olarak değerlendirilir. Puanlama işlemi bittikten sonra çocuğun her gelişim alanından aldığı puanlar toplanarak alt testlere ait ham puanlar elde edilmektedir. Ham puanlar GEÇDA Formu'nda yer alan grafikler üzerinde işaretlenerek çocuğun durumu değerlendirilmektedir (Temel, Ersoy, Avcı ve Turla, 2016).

\section{Frostig Gelişimsel Görsel Alg1 Testi (DTVP)}

Frostig Görsel Alg1 Testi çocukların görsel algılama becerilerini değerlendirmek amacıyla Frostig (1961) tarafindan geliştirilmiş ve Maslow, Frostig, Lefever ve Whittlesey (1963) tarafindan, 3- 9 yaşlar arası 2116 normal gelişim gösteren çocukla yapılan çalışmalar sonucunda standardize edilmiştir. Test; el-göz koordinasyonu, şekil zemin ayrımı, şekil sabitliği algısı, mekân ile konum ilişkisi alg1sı ve mekânsal ilişkiler alg1sı olmak üzere beş algısal beceriyi ölçmektedir. Frostig Görsel Alg1 Testi çocuğa bireysel olarak uygulanmaktadır. Uygulama yaklaşık 25-30 dakika sürmektedir. Değerlendirme yapılırken her bir alt boyut kendi içinde değerlendirilerek puanlanmaktadır. Ölçeğin toplamından alınabilecek en yüksek puan 83 puandır (Tepeli, 2013; Aral ve Bütün Ayhan, 2016).

Sökmen (1994) tarafından 5-6 çocukları için yapılan güvenirlik çalışmasında, Frostig Görsel Alg1 Testi'nin genel ve alt boyutlardaki devamlılık katsayılarının 0.01 düzeyinde anlamlı olduğu bulunmuştur. Testin, dört-yedi yaş aralı̆̆ındaki Türk çocuklarına uyarlanması ise, Aral ve Bütün Ayhan (2016) tarafindan yapılmıştır. Veriler dört-yedi yaş arasındaki 1382 çocuktan elde edilmiştir. 
Araştırma sonucunda elde edilen bulgular Frostig Görsel Alg1 Testi'nin Türkçe formunun dört-yedi yaşlar arasındaki çocuklar için geçerli ve güvenilir bir ölçme aracı olduğunu göstermiştir.

\section{Veri Toplama Süreci}

Veri toplama süreci için İstanbul Valiliği İl Milli Eğitim Müdürlüğü’nden gerekli izinler alınmıştır. Uygulama yapılacak okullarda okul yöneticisi ve öğretmenler çalışma ile ilgili bilgilendirilmiştir. Çocukların ebeveynlerine çalışma ile ilgili bilgilendirici yazı ve izin formu gönderilmiş; ebeveyni izin veren çocuklar çalışma grubuna dâhil edilmiştir. Çalışma grubunu oluşturan çocuklarla tanışılarak süreç hakkında bilgi verilmiştir. Uygulamalar, çocukların dikkatini dağıtmayacak niteliğe ve kaba motor oyunlarının gerçekleştirilmesi için uygun büyüklük ve fiziksel özelliklere sahip bir alanda her çocukla bireysel çalısma yapılarak araştırmacı tarafından gerçekleştirilmiştir. Uygulama, çocuğun kronolojik yaşı, motor performansı, etkinliklere katılım ve uyum düzeyine bağlı olarak ortalama 4060 dakika sürmektedir. Öncelikle, 15 çocukla ölçme aracının pilot uygulaması yapılarak oluşabilecek sorunlar gözden geçirilmiş ve gerekli önlemler alınmıştır.

Araştırmanın verileri, çalışma grubunu oluşturan çocuklar ile "Miller Fonksiyon ve Katılım Ölçeği" kullanarak yapılan birebir çalışmalarla ve çocukların ebeveynlerinden "Kişisel Bilgi Formu” yoluyla edinilen bilgilerle elde edilmiştir. Ölçüt geçerliği için rasssal olarak seçilen 30 çocuğa "Gazi Erken Çocukluk Gelişimi Değerlendirme Aracı" ve 50 çocuğa "Frostig Gelişimsel Görsel Alg1 Testi” birebir çalışma yapılarak araştırmacı tarafından uygulanmıştır. Uygulamaların tamamlanmasının ardından kişisel bilgi formları ve test kayıt formaları incelenmiş ve eksik bilgilerin olduğu formlar araştırmanın verileri arasına dâhil edilmemiştir.

\section{Verilerin Analizi}

Elde edilen veriler SPSS paket programı aracılloğılla analiz edilmiş ve çözümlenmiştir. Ölçeğin geçerlik ve güvenirlik çalısmasına ilişkin olarak aşă̆ıdaki istatistik işlem ve analizler gerçekleştirilmiştir:

Miller Fonksiyon ve Katılım Ölçeği’nin geçerlik çalışması kapsamında,

- Uyarlama sürecinde akademisyen, dil ve alan uzmanlarından alınan uzman görüşleri uyarlanan ölçeğin içerik geçerliğinin olduğu hakkında kanıt sunmaktadır.

- Ölçeğin yapı geçerliliği açısından değerlendirilmesi için motor gelişimin alt alanlarının her birinin birbiri ile ilişkisinin sıfır sıralı order ve kısmı korelasyon analizleri yapılmıştır. 
- Uyum geçerliğini sınamak amacıyla Gazi Erken Çocukluk Gelişimi Değerlendirme Aracı ve Frostig Gelişimsel Görsel Alg1 Testi ile korelasyonu incelenmiştir.

- Gelişimsel geçerliğini sınamak amacıyla çocukların görsel, ince ve kaba motor puanlarının yaşa göre farklılaşıp farklılaşmadı̆̆ı incelenmiştir.

- Özel gruplar arası ayırt edici geçerliğini sınamak amacıyla tipik motor gelişimi gösteren çocuklar ile özel eğitim tanısı almış ve görsel, ince ve kaba motor gelişim alanlarından bir ya da daha fazlasında gecikmesi olan çocukların puan ortalamaları karşılaştırılmıştır.

Miller Fonksiyon ve Katılım Ölçeği’nin güvenirlik çalışması kapsamında,

- Ölçeğin alt testlerinin güvenirliği iç tutarlılık katsayısının (Cronbach Alfa) hesaplanmasıyla elde edilmiştir.

- Ölçeğin alt testlerinin güvenirliği için alt testlerden elde edilen puanların yaşa göre ölçmenin standart hata puanları hesaplanmıştır.

- Test-tekrar test güvenirliği için korelasyon katsayıları hesaplanmıştır.

- Bağımsız değerlendiriciler arası tutarlı1ık korelasyon katsayısı hesaplanmıştır.

\section{BULGULAR}

Bu bölümde Miller Fonksiyon ve Katılım Ölçeği Türkçe formunun 48-95 ay arası çocuklar için geçerlik ve güvenirliğine ilişkin bulgular yer almaktadır.

\section{Miller Fonksiyon ve Katılım Ölçeği'nin Geçerliğine İlişkin Bulgular}

Geçerlik, bir değerlendirme aracının ölçmeyi amaçladığı özelliği ne kadar iyi ölçtüğünün bir ölçüsüdür. Birçok farklı geçerlik türü vardır. Değişen sosyal ve klinik bağlam nedeniyle akışkan bir süreçtir. Testin geçerliliğini sürdürdüğünden emin olmak için, testin kullanılacağı veya kullanıldığ1 farklı coğrafi, kültürel ve sosyoekonomik durumlarda periyodik olarak çalışılmalıdır (Dunn, 1989; Akt. Diemand ve Case-Smith, 2013, s. 204).

Bu kısımda, 48-95 ay arası çocuklar için Miller Fonksiyon ve Katılım Ölçeği’nin yapı geçerliğine, diğer değişkenlerle olan ilişkisine ve klinik ayırt edicilik istatistiklerine dayalı olarak geçerlik kanıtı sunulmuş ve bu kanıtlara ilişkin bulgulara yer verilmiştir. 


\section{Yap1 Geçerliği}

Miller Fonksiyon ve Katılım Ölçeği'nin yapı geçerliği açısından incelenmesi amacıyla her bir alt motor gelişim alanının birbiri ile ilişkinin sıfır sıralı ve kısmı korelasyon analizleri yapılmıştır. Sıfır sıralı korelasyon analizine ilişkin bulgular Tablo 3’te verilmiştir.

Tablo 4. Çalışma grubunu oluşturan çocukların Miller Fonksiyon ve Katılım Ölçeği alt testlerinden aldıkları puanların sıfır sıralı korelasyon analizi sonuçları

\begin{tabular}{lccc}
\hline Test & GM & IM & KM \\
\hline Görsel Motor & & $.76^{*}$ & $.85^{*}$ \\
İnce Motor & & & $.71^{*}$ \\
Kaba Motor & 76,18 & 109,23 & 115,92 \\
\hline $\bar{x}$ & 13,00 & 11,20 & 28,72 \\
\hline $\mathrm{SS}$ & 250 & 250 & 250 \\
\hline $\mathrm{N}$ & & &
\end{tabular}

Tablo 4. incelendiğinde, Miller Fonksiyon ve Katılım Ölçeği motor gelişim alanlarının sıfır sıralı korelasyon sonuçlarının .71 ila .85 arasında değiştiği görülmektedir. Bu değerler motor gelişimin görsel, ince ve kaba motor alanlarının yüksek derecede anlamlı bir ilişkiye sahip olduğunu göstermektedir. Bu durumun ayrımına net olarak varabilmek amacıyla yaş değişkenini kontrol altında tutarak testin alt alanlarının toplam puanları üzerinden hesaplanan kısmi korelasyon analizine ilişkin bulgular Tablo 5’te verilmiştir.

Tablo 5. Çalışma grubunu oluşturan çocukların Miller Fonksiyon ve Katılım Ölçeği alt testlerinden aldıkları puanların kısmi korelasyon analizi sonuçları

\begin{tabular}{lllll}
\hline Kontrol Değişkeni & Test & GM & IM & KM \\
\hline & Görsel Motor & & $.46^{*}$ & $.41^{*}$ \\
& İnce Motor & & & $.32^{*}$ \\
Yaş & Kaba Motor & & \\
\hline${ }_{\mathrm{p}<.001}$ & & &
\end{tabular}

Tablo 5 incelendiğinde, yaş değişkenini kontrol altında tutarak alt alanların toplam puanları üzerinden hesaplanan kısmi korelasyon sonucunun sıfır sıralı korelasyon sonuçlarına göre daha düşük oldukları (.32-.46) görülmektedir. Bu durum, Miller Fonksiyon ve Katılım Ölçeği’nin alt alanlarının (görsel, ince ve kaba motor) birbirleriyle hem ilişkili olduğu hem de motor gelişimin farklı yönlerini ölçtüğ̈nü ortaya koymaktadır.

\section{Uyum Geçerliği: Gazi Erken Çocukluk Gelişimi Değerlendirme Aracı İle Olan İlişki}

Ölçüt geçerliği, bir ölçme aracının puanlarının ölçülen yapıyla kavramsal olarak ilişkili olan dış ölçümlere karşılık geldiğini veya yordadığını gösteren bulgudur (Field, 2016, s. 705). Uyum geçerliği, 
bir değerlendirme puanlarının test edilen alanda kabul edilmiş olan bir başka değerlendirme ile ilişkilendirilmesiyle belirlenir (Diemand ve Case-Smith, 2013, s. 205).

Genel olarak aynı veya benzer yapıları ölçtügü iddia edilen motor gelişim testlerinin bir dereceye kadar ilişki göstermeleri beklenir. Miller Fonksiyon ve Katılım Ölçeği’nin uyum geçerliğini sınamak amacıyla Türkiye'de kullanılan motor gelişim ölçekleri içerisinde kaba, ince ve görsel motor alanlarının tümünü kapsayan tek bir ölçek bulunmadığı için iki farklı değerlendirme aracı kullanılmıştır. Miller Fonksiyon ve Katılım Ölçeği’nin İnce Motor ve Kaba Motor alanları için Gazi Erken Çocukluk Gelişimi Değerlendirme Aracı ile korelasyonu incelenmiştir.

Ancak Gazi Erken Çocukluk Gelişimi Değerlendirme Aracı 0-72 ay çocuklara yönelik olduğu için çalışma grubu içinde yer alan 72 aylıktan büyük çocuklara uygulanamamıştır. Bu nedenle kaba ve ince motor alanlarında ölçüt geçerliğine sadece $48-72$ ay arasındaki çocuklar dâhil edilmiştir $(n=30)$. Ölçümler arası korelasyon yaş gruplarında Spearman-Brawn; tüm grupta ise Pearson Korelasyon Katsayısı ile test edilmiştir.

Miller Fonksiyon ve Katılım Ölçeği İnce ve Kaba Motor alanı ile Gazi Erken Çocukluk Gelişimi Değerlendirme Aracı'nın İnce ve Kaba Motor alt ölçek puanları arasındaki ilişkiyi belirlemek üzere korelasyon analizi sonuçları Tablo 6.'da verilmiştir.

Tablo 6. Miller Fonksiyon ve Katılım Ölçeği ile Gazi Erken Çocukluk Gelişimi Değerlendirme Aracı korelasyon sonuçları

\begin{tabular}{llll}
\hline Yaş Gruplar1 & & $\begin{array}{l}\text { GEÇDA } \\
\text { Ince Motor }\end{array}$ & $\begin{array}{l}\text { GEÇDA } \\
\text { Kaba Motor }\end{array}$ \\
\hline $\begin{array}{l}48-53 \text { ay } \\
(\mathrm{N}=10)\end{array}$ & M-FUN İnce Motor & $.93^{* *}$ & $.97^{* *}$ \\
& M-FUN Kaba Motor & & \\
$54-59$ ay & M-FUN İnce Motor & $.88^{* *}$ & $.97^{* *}$ \\
$(\mathrm{~N}=10)$ & M-FUN Kaba Motor & & $.91^{* *}$ \\
$60-71$ ay & M-FUN İnce Motor & .53 & \\
$(\mathrm{~N}=10)$ & M-FUN Kaba Motor & & $.94^{* *}$ \\
$48-71$ ay & M-FUN İnce Motor & $.74^{* *}$ & \\
$(\mathrm{~N}=30)$ & M-FUN Kaba Motor & &
\end{tabular}

Tablo 6. incelendiğinde, Miller Fonksiyon ve Katılım Ölçeği uyum geçerliği için çalışma grubunun Gazi Erken Çocukluk Gelişimi Değerlendirme Aracı'ndan aldıkları toplam puanlar ile Miller Fonksiyon ve Katılım Ölçeği toplam puanları arasında hesaplanan korelasyon 48-71 ay çocuklarda İnce Motor alanı için .74 $(\mathrm{p}<.01)$; Kaba Motor alanı için ise $.94(\mathrm{p}<.01)$ olarak bulunmuştur. 
Ölçümler arası korelasyona yaş gruplarına göre bakıldığında, 60-71 ay arası çocuklar dışında .88 $(\mathrm{p}<.01)$ ve üzerinde olduğu görülmektedir.

\section{Uyum Geçerliği: Frostig Gelişimsel Görsel Alg1 Testi İle Olan İlişki}

Miller Fonksiyon ve Katılım Ölçeği’nin Görsel Motor alanı için Frostig Gelişimsel Görsel Alg1 Testi ile korelasyonu incelenmiştir. Frostig Gelişimsel Görsel Alg1 Testi 3-9 yaş çocuklarına uygulanabildiği için görsel motor ölçeğinde tüm yaş gruplanı uyum geçerliği açısından incelenmiştir $(\mathrm{n}=50)$.

Miller Fonksiyon ve Katılım Ölçeği görsel motor alanı ile Frostig Gelişimsel Görsel Alg1 Testi puanları arasındaki ilişkiyi belirlemek üzere korelasyon analizi sonuçları Tablo 7'de verilmiştir.

Tablo 7. Miller Fonksiyon ve Katılım Ölçeği ile Frostig Gelişimsel Görsel Alg1 Testi korelasyon sonuçları

\begin{tabular}{ll}
\hline Yaş Gruplar1 & $\mathrm{r}$ \\
\hline $48-53$ ay $(\mathrm{N}=10)$ & $.92^{* *}$ \\
$54-59$ ay $(\mathrm{N}=10)$ & $.99 * *$ \\
$60-71$ ay $(\mathrm{N}=10)$ & $.93^{* *}$ \\
$72-83$ ay $(\mathrm{N}=10)$ & $.87 * *$ \\
$84-95$ ay $(\mathrm{N}=10)$ & $.68^{*}$ \\
$48-95$ ay $(\mathrm{N}=50)$ & $.94 * *$ \\
\hline$* * \mathrm{p}<.01 \quad{ }^{*} \mathrm{p}<.05$ &
\end{tabular}

Tablo 7 incelendiğinde, Miller Fonksiyon ve Katılım Ölçeği görsel motor alanın uyum geçerliği için kullanılan, Frostig Gelişimsel Görsel Alg1 Testi'nden aldıkları toplam puanlar ile Miller Fonksiyon ve Katılım Ölçeği görsel motor alanı toplam puanları arasında hesaplanan korelasyon .94’tür ( $\mathrm{p}<.01)$. Ölçümler arası korelasyon yaş gruplarında .68 ve .99 arasında değişmektedir.

Diemand (2009) tarafından yapılan Miller Fonksiyon ve Katılım Ölçeğı'nin ölçüt geçerliği çalışmasinda, 54 ve 78 ay arası toplam 40 çocuğun Developmental Test of Visual Perception, Second Edition (DTVP-2) puanları ile Miller Fonksiyon ve Katılım Ölçeği’nin Görsel Motor puanlarının korelasyonu incelenmiştir. İki test arasındaki korelasyon $(\mathrm{r}=.872 ; \mathrm{p}<.001)$ yüksek düzeyde bulunmuştur.

\section{Gelişimsel Geçerlik}

Motor gelişim, durağan değil, sürekli gelişen dinamik bir yapıya sahiptir. Motor gelişim evreleri, zaman içerisinde hareket davranışındaki değişiklikleri temel alarak kendini göstermektedir (Gallahue, Ozmun ve Goodway, 2014, s. 48). Bu nedenle yaş ilerledikçe çocuğun motor becerilerinde daha fazla yetkinlik kazanması ve ustalaşması beklenir. Yaş gruplarına göre Miller 
Fonksiyon ve Katılım Ölçeği'nin görsel, ince ve kaba motor ham puanlarının ortalama ve standart sapmaları Tablo 8'de verilmiştir.

Tablo 8. Yaş gruplarına göre Miller Fonksiyon ve Katılım Ölçeği’nin görsel, ince ve kaba motor ham puanlarınin ortalama ve standart sapmaları

\begin{tabular}{lcccc}
\hline Test & Yaş grubu & $\mathrm{N}$ & $\overline{\boldsymbol{x}}$ & SS \\
\hline Görsel Motor & $48-53$ ay & 54 & 60,67 & 8,739 \\
& $54-59$ ay & 43 & 68,86 & 5,392 \\
& $60-71$ ay & 53 & 74,47 & 7,655 \\
& $72-83$ ay & 46 & 85,52 & 5,324 \\
& $84-95$ ay & 54 & 91,24 & 3,865 \\
\hline İnce Motor & Toplam & 250 & 76,18 & 13,003 \\
& $48-53$ ay & 54 & 97,22 & 10,344 \\
& $54-59$ ay & 43 & 105,23 & 6,410 \\
& $60-71$ ay & 53 & 109,13 & 11,144 \\
& $72-83$ ay & 46 & 116,13 & 4,655 \\
\hline Kaba Motor & $84-95$ ay & 54 & 118,65 & 4,230 \\
& Toplam & 250 & 109,23 & 11,200 \\
& $48-53$ ay & 54 & 86,83 & 11,691 \\
& $54-59$ ay & 43 & 96,65 & 10,424 \\
& $60-71$ ay & 53 & 102,68 & 11,454 \\
& $72-83$ ay & 46 & 140,30 & 15,625 \\
\hline & $84-95$ ay & 54 & 152,56 & 9,805 \\
\hline
\end{tabular}

Miller Fonksiyon ve Katılım Ölçeği'nin gelişimsel geçerliğini incelemek amacıyla 48-95 ay aralığındaki çocukların görsel, ince ve kaba motor alanlarından elde ettikleri ham puanlar yaş gruplarına göre karşılaştırılmış ve tek yönlü varyans analizi sonuçları Tablo 9'de verilmiştir.

Tablo 9. Miller Fonksiyon ve Katılım Ölçeği’nin görsel, ince ve kaba motor ham puanlarının yaş gruplarına göre karşılaştırılması için yapılan varyans analizi sonuçları

\begin{tabular}{lcc}
\hline Test & $\mathrm{F}$ & $\mathrm{P}$ \\
\hline Görsel Motor & 187,09 & .000 \\
İnce Motor & 59,99 & .000 \\
Kaba Motor & 301,34 & .000 \\
\hline
\end{tabular}

Tablo 9. İncelendiğinde, Miller Fonksiyon ve Katılım Ölçeği’nin görsel, ince ve kaba motor ham puanlarının yaş gruplarına göre karşılaştırılması için yapılan varyans analizi sonuçlarına göre tüm motor gelişim alanları yaş gruplarına göre anlamlı şekilde farklılaşmaktadır. Hangi yaş grupları arasında anlamlı farklılaşma olduğunu incelemek amacıyla yapılan çoklu karşılaştırma testleri sonucunda, 72-83 ay ve 84-95 ay arası çocukların İnce Motor puanları dışında tüm yaş grupları arasında anlamlı farklilık bulunmuştur $(\mathrm{p}<.001)$. 


\section{Özel Gruplar Arası Ayırt Edici Geçerlik}

Motor gelişim testlerinin kullanımının birincil amacı motor fonksiyon yönünden yüksek veya düşük olan bireyleri tanılamaktır. Bu nedenle motor gelişim testlerinin geçerliğinin en önemli kanıtlarından biri gruplar arası ayırt ediciliğidir. Örneğin motor gelişim gecikmesi olan otizm, down sendromu, gelişimsel koordinasyon bozukluğu tanısı almış veya motor fonksiyon sorunları olan çocuklar tipik gelişim gösteren çocuklara kıyasla motor gelişim testlerinden daha düşük puan alırlar. Bu tablonun Miller Fonksiyon ve Katılım Ölçeği puanlarına da yansıması beklenmelidir. Diğger bir deyişle, motor gelişim gecikmesi veya benzer motor fonksiyon sorunu olan çocukların Miller Fonksiyon ve Katılım Ölçeği puanları tipik motor beceri gelişimi gösteren çocukların Miller Fonksiyon ve Katılım Ölçeği puanına kıyasla çok daha düşük olmalıdır. Bu çalışma, Miller Fonksiyon ve Katılım Ölçeği’nin her bir motor alanını ve onların alt ölçek puanlarının motor gecikmesi olan çocuklar ile tipik motor becerileri gösteren çocuklar arasında ne kadar farklılaştığını belirlemek amacıyla yapılmıştır.

Klinik grupları ayırt etme geçerliğini araştırmak için özel eğitim tanısı almış ve motor gelişim gecikmesi olduğu belirlenmiş 12 çocuk ve tipik gelişim gösteren 12 çocuk olmak üzere 48-95 ay arası toplam 24 çocuğa Miller Fonksiyon ve Katılım Ölçeği uygulanmıştır. Özel eğitim tanısı almış ve motor gelişim gecikmesi olduğu belirlenmiş çocukların yaş ortalaması 67 ay (5 yaş 7 ay) olan 12 çocuğun 3'ü Kadıköy ilçesinde, 9'u Pendik ilçesinde olmak üzere tamamı Özel Eğitim ve Rehabilitasyon Merkezi'nde bireysel eğitim almaktadır. Aynı zamanda 6 çocuk okul öncesi eğitim sınıfina, 1 çocuk ilkokul birinci sınıfa kaynaştırma öğrencisi olarak devam etmektedir. 1 çocuk ilkokul bünyesinde özel eğitim alt sınıfında öğrenim görmektedir. 9 çocuk ise "Aktifim Toplumun İçindeyim Projesi” kapsamında Bütünleşik Fiziksel Aktivite Merkezine devam etmektedir.

Rehberlik Araştırma Merkezi tarafından herhangi bir özel eğitim tanısı almamış ve tipik motor beceri gelişimi gösteren çocuklardan 8’i İl Milli Ë̆itim Bakanlığı'na bağlı bağımsız anaokulunun okul öncesi eğitim sınıfına, 4’ü ise bir devlet okulunun ilkokul 1. sınıfina devam etmektedir. Miller Fonksiyon ve Katılım Ölçeği klinik ayırt edicilik çalışma grubunun özellikleri Tablo 10'da verilmiştir.

Tablo 10. Miller Fonksiyon ve Katılım Ölçeği klinik ayırt edicilik çalışma grubunun özellikleri

\begin{tabular}{llccc}
\hline & & & \multicolumn{2}{c}{ Cinsiyet } \\
\cline { 3 - 5 } Grup & N & Yaş Ortalaması (Ay) & Kız & Erkek \\
\hline Zihinsel Gelişim Yetersizliği & 2 & & 2 & 2 \\
Otizm & 9 & 66 & 1 & 7 \\
DEHB & 1 & & 8 & - \\
Tipik Gelişim & 12 & 67 & 4 \\
\hline
\end{tabular}


Tipik gelişim gösteren çocuklar ile motor gelişim gecikmesi olan çocukların Miller Fonksiyon ve Katılım Ölçeği 'nden aldıkları görsel, ince ve kaba motor puanlarının karşılaştırılmasına ilişkin sonuçlar Tablo 11'de verilmiştir.

Tablo 11. Tipik gelişim gösteren çocuklar ile motor gelişim gecikmesi olan çocukların motor gelişim puanlarını karşılaştırma sonuçları

\begin{tabular}{|c|c|c|c|c|c|c|c|}
\hline \multirow{2}{*}{ Test } & \multirow{2}{*}{ Gruplar } & \multirow{2}{*}{$\mathrm{N}$} & \multirow{2}{*}{ S.O. } & \multirow{2}{*}{ S.T. } & \multirow{2}{*}{$\mathrm{U}$} & \multirow[b]{2}{*}{ Z } & \multirow[b]{2}{*}{$\mathrm{p}$} \\
\hline & & & & & & & \\
\hline \multirow[t]{2}{*}{ Görsel Motor } & Tipik Gelişim & 12 & 18.50 & 222 & \multirow{2}{*}{144.00} & \multirow{2}{*}{4.158} & \multirow{2}{*}{.000} \\
\hline & Atipik Gelişim & 12 & 6.50 & 78 & & & \\
\hline \multirow[t]{2}{*}{ İnce Motor } & Tipik Gelişim & 12 & 18.29 & 219.48 & \multirow{2}{*}{141.50} & \multirow{2}{*}{4.017} & \multirow{2}{*}{.000} \\
\hline & Atipik Gelişim & 12 & 6.71 & 80.52 & & & \\
\hline \multirow[t]{2}{*}{ Kaba Motor } & Tipik Gelişim & 12 & 18.50 & 222 & \multirow{2}{*}{144.00} & \multirow{2}{*}{4.158} & \multirow{2}{*}{.000} \\
\hline & Atipik Gelişim & 12 & 6.50 & 78 & & & \\
\hline
\end{tabular}

Tablo 11 incelendiğinde, tipik gelişim gösteren çocuklar ile motor gelişim gecikmesi olan çocukların tüm motor gelişim alanlarında puanlarının anlamlı düzeyde farklılaştığı görülmektedir $(\mathrm{p}<.001)$. Aynı zamanda puanlar motor gelişimin Görsel Motor (8 alt test), İnce Motor (5 alt test) ve Kaba Motor (6 alt test) alanlarının alt testleri dikkate alınarak incelenmiş ve tüm alt testlerde anlamlı farklılık bulunmuştur $(\mathrm{p}<.01)$. Bu sonuçlar, Miller Fonksiyon ve Katılım Ölçeği’nin 48-95 ay arası motor gecikmeleri olan çocukların belirlenmesinde kullanılabileceğine dair kanıt sağlamaktadır. Miller Fonksiyon ve Katılım Ölçeği’nin bir çocuğun görsel, ince ve kaba motor işleme alanında bir gecikmesi olup olmadığını belirlerken uygulayıcılar için geçerli bir değerlendirmede bulunduğunu göstermektedir.

\section{Miller Fonksiyon ve Katılım Ölçeği'nin Güvenirliğine İlişkin Bulgular}

Güvenirlik, bir araştırmanın, yanıtlanması amaçlanan soru hakkında doğru çıkarımlara izin verdiğinin veya bir testin kavramsal olarak ölçmeyi amaçladığını ölçmesinin kanıtıdır (Field, 2016, s. 725). Güvenirlik terimi genel olarak, bir dizi ölçüm prosedürünün zamansal stabilitesini tanımlamak, iç tutarlılık ve prosedürlerin farklı değerlendiriciler arası uyumu ile ilgilidir. Bu farklı kullanımların hepsi tek bir kavramda, yani testin veya prosedür setinin kullanımından kaynaklanan puanlarla ilişkili hatanın etkisinin tahmin edilmesinde yoğunlaşmaktadır (Franzen, 2002, s.7).

Miller Fonksiyon ve Katılım Ölçeği’nin güvenirliğinin sınanmasında iç tutarlılık katsayısı, yaş gruplarına göre ölçmenin standart hatası, test-tekrar test güvenirlik katsayısı ve bağımsız değerlendiriciler arası güvenirlik katsayısı bulguları aşağıda verilmiştir. 


\section{İç Tutarlılık}

Miller Fonksiyon ve Katılım Ölçeği’ndeki maddelerin iç tutarlılık güvenirliği Cronbach'ın alfa katsayısı kullanılarak araştırılmıştır. Yaşlara göre Miller Fonksiyon ve Katılım Ölçeği’nin alt alanları için güvenirlik katsayıları Tablo 12’ de sunulmuştur.

Tablo 12. Miller Fonksiyon ve Katılım Ölçeği’nin yaşlara göre iç tutarlılık güvenirliğine ilişkin Cronbach Alfa analizi sonuçları

\begin{tabular}{lcccccc}
\hline Test & $\begin{array}{c}48-53 \text { ay } \\
(\mathrm{n}=54)\end{array}$ & $\begin{array}{c}54-59 \text { ay } \\
(\mathrm{n}=43)\end{array}$ & $\begin{array}{c}60-71 \text { ay } \\
(\mathrm{n}=53)\end{array}$ & $\begin{array}{c}72-83 \text { ay } \\
(\mathrm{n}=46)\end{array}$ & $\begin{array}{c}84-95 \text { ay } \\
(\mathrm{n}=54)\end{array}$ & $\begin{array}{c}48-95 \text { ay } \\
(\mathrm{n}=250)\end{array}$ \\
\hline Görsel Motor & .87 & .71 & .78 & .61 & .65 & .91 \\
İnce Motor & .93 & .87 & .88 & .71 & .75 & .90 \\
Kaba Motor & .92 & .89 & .87 & .91 & .86 & .93 \\
\hline
\end{tabular}

Tablo 12'de iç tutarlılık sonuçları incelendiğinde, 48-53 ay arası iç tutarlılık katsayıları Görsel Motor için .87, İnce Motor için .93, Kaba Motor için .92 bulunmuştur. 54-59 ay arası iç tutarlılık katsayıları Görsel Motor için .71, İnce Motor için .87, Kaba Motor için .89 bulunmuştur. 60-71 ay arası iç tutarll1ık katsayılanı Görsel Motor için .78, İnce Motor için .88, Kaba Motor için .87 bulunmuştur. 72-83 ay arası iç tutarlılık katsayıları Görsel Motor için .61, İnce Motor için .71, Kaba Motor için .91 bulunmuştur. 84-95 ay arası iç tutarll1ık katsayıları Görsel Motor için .65, İnce Motor için .75, Kaba Motor için .86 bulunmuştur. Ölçeğin geneli için bakıldı̆̆ında, 48-95 ay arası iç tutarlılık katsayılarının Görsel Motor için .91, İnce Motor için .90, Kaba Motor için .93 olduğu görülmektedir.

Miller Fonksiyon ve Katılım Ölçeği alt testleri için ölçümle ilişkilendirilmişs standart hata puanları Tablo 13'de yer almaktadır.

Tablo 13. Miller Fonksiyon ve Katılım Ölçeği'nin görsel motor, ince motor ve kaba motor puanlarında yaş gruplarına göre ölçmenin standart hatası

\begin{tabular}{|c|c|c|c|c|c|}
\hline Test & Yaş grubu & $\min$ & $\max$ & $\bar{x}$ & Standart Hata \\
\hline \multirow{5}{*}{ Görsel Motor } & $48-53$ ay & 40 & 79 & 60,67 & 1.18 \\
\hline & 54-59 ay & 55 & 79 & 68,86 & .82 \\
\hline & 60-71 ay & 54 & 89 & 74,47 & 1.05 \\
\hline & $72-83$ ay & 76 & 95 & 85,52 & .78 \\
\hline & 84-95 ay & 77 & 95 & 91,24 & .52 \\
\hline \multirow[t]{5}{*}{ İnce Motor } & 48-53 ay & 70 & 116 & 97,22 & 1.40 \\
\hline & 54-59 ay & 89 & 117 & 105,23 & .97 \\
\hline & 60-71 ay & 65 & 122 & 109,13 & 1.53 \\
\hline & $72-83$ ay & 106 & 122 & 116,13 & .68 \\
\hline & $84-95$ ay & 101 & 122 & 118,65 & .57 \\
\hline \multirow[t]{4}{*}{ Kaba Motor } & 48-53 ay & 52 & 110 & 86,83 & 1.59 \\
\hline & 54-59 ay & 79 & 118 & 96,65 & 1.59 \\
\hline & $60-71$ ay & 66 & 121 & 102,68 & 1.57 \\
\hline & $72-83$ ay & 100 & 165 & 140,30 & 2.30 \\
\hline
\end{tabular}


Tablo 13 incelendiğinde, 48-53 ay arası çocuklar için ölçmenin standart hata puanının Görsel Motor testinde 1.18, İnce Motor testinde 1.40 ve Kaba Motor testinde 1.59 olduğu görülmektedir. 54-59 ay arası çocuklar için ölçmenin standart hata puanının Görsel Motor testinde .82, İnce Motor testinde .97 ve Kaba Motor testinde 1.59 olduğu görülmektedir. 60-71 ay aras1 çocuklar için ölçmenin standart hata puanının Görsel Motor testinde 1.05, İnce Motor testinde 1.53 ve Kaba Motor testinde 1.57 olduğu görülmektedir. $72-83$ ay aras1 çocuklar için ölçmenin standart hata puanının Görsel Motor testinde .78, İnce Motor testinde .68 ve Kaba Motor testinde 2.30 olduğu görülmektedir. 84-95 ay arası çocuklar için ölçmenin standart hata puanının Görsel Motor testinde .52 , Ince Motor testinde .57 ve Kaba Motor testinde 1.33 olduğu görülmektedir.

Ölçmenin standart hatası, hata miktarını tahmin eden ve test güvenirlik katsayıları ve test puanlarının değişkenliği (Standart sapma) ile doğrudan ilişkili olan bir istatistik işlemdir. Tek bir puan için ölçmenin standart hatası, "gerçek" puan civarında elde edilen puanlarda beklenen değişkenliği gösterir. Başka bir deyişle, ölçüm hatası, aynı koşullar altında aynı ölçme aracı tekrar tekrar uygulandığında çocuğun puanının ne kadar değişebileceğini gösterir (Miller, 2006, s. 104). Miller Fonksiyon ve Katılım Ölçeği’nin Görsel Motor, İnce Motor ve Kaba Motor puanları için yaş gruplarına göre ölçümle ilişkilendirilmiş standart hata puanlarının düşük olduğu görülmektedir. Bu durum, yüksek test güvenirliği derecesini desteklemektedir.

\section{Test-Tekrar Test Güvenirliği}

Test tekrar test güvenirliği, bir dizi ölçüm prosedürünün zamansal stabilitesini tanımlamak için kullanılır (Franzen, 2002, s. 7). Aynı özelliklerin kısa bir zaman aralığıyla iki defa test edilmesiyle ortaya çıkan tutarlı sonuçlara göre bir ölçü yeteneğidir (Field, 2016, s. 724). Cronbach'a (1990) göre test-tekrar test katsayıs1, kararlılık göstergesidir (Gliner, Morgan ve Leech, 2015, s. 157).

Miller Fonksiyon ve Katılım Ölçeği'nin Test-Tekrar Test Güvenirliği için her yaş grubundan 10 çocuk olmak üzere tüm yaş gruplarındaki çocuklardan rastgele örnekleme yöntemi ile seçilen 50 çocuk iki hafta ara ile test edilmiştir. Ölçümler arası korelasyon yaş gruplarında Spearman-Brawn; tüm grupta ise Pearson Korelasyon Katsayısı ile test edilmiştir. Görsel, ince ve kaba motor alanlarının puanı için ortalama, standart sapma ve korelasyon katsayıları Tablo 14'de verilmiştir.

Tablo 14. Miller Fonksiyon ve Katıllım Ölçeği’nin test-tekrar test güvenirliğine dair ortalama, standart sapma ve korelasyon katsayiları

\begin{tabular}{|c|c|c|c|c|c|c|}
\hline & & \multicolumn{2}{|c|}{ Ölçüm 1} & \multicolumn{2}{|c|}{ Ölçüm 2} & \\
\hline Yaş Grupları & Alt Testler & $\overline{\bar{x}}$ & Ss & $\bar{x}$ & Ss & $\mathrm{r}$ \\
\hline
\end{tabular}




\begin{tabular}{|c|c|c|c|c|c|c|}
\hline \multirow{3}{*}{$\begin{array}{l}48-53 \text { ay } \\
(\mathrm{N}=10)\end{array}$} & Görsel Motor & 65.80 & 10.04 & 65.90 & 11.04 & $.99 * *$ \\
\hline & İnce Motor & 110.70 & 8.69 & 111.00 & 8.36 & $.98^{* *}$ \\
\hline & Kaba Motor & 94.10 & 7.38 & 94.30 & 7.86 & $.96^{* *}$ \\
\hline \multirow{3}{*}{$\begin{array}{l}54-59 \text { ay } \\
(\mathrm{N}=10)\end{array}$} & Görsel Motor & 72.30 & 5.37 & 72.60 & 6.38 & $.96^{* *}$ \\
\hline & İnce Motor & 110.30 & 7.74 & 110.60 & 7.12 & $.99 * *$ \\
\hline & Kaba Motor & 100.40 & 9.99 & 100.00 & 10.02 & $.95^{* *}$ \\
\hline \multirow{3}{*}{$\begin{array}{l}60-71 \text { ay } \\
(\mathrm{N}=10)\end{array}$} & Görsel Motor & 79.90 & 7.51 & 79.90 & 6.60 & $.94 * *$ \\
\hline & Ínce Motor & 115.60 & 6.14 & 115.80 & 6.12 & $.99 * *$ \\
\hline & Kaba Motor & 104.80 & 5.69 & 104.80 & 6.14 & $.91 * *$ \\
\hline \multirow{3}{*}{$\begin{array}{l}72-83 \text { ay } \\
(\mathrm{N}=10)\end{array}$} & Görsel Motor & 91.20 & 2.74 & 91.70 & 3.23 & $.91 * *$ \\
\hline & İnce Motor & 114.20 & 3.79 & 114.50 & 4.06 & $.94 * *$ \\
\hline & Kaba Motor & 142.20 & 15.88 & 141.60 & 15.90 & $.98^{* *}$ \\
\hline \multirow{3}{*}{$\begin{array}{l}84-95 \text { ay } \\
(\mathrm{N}=10)\end{array}$} & Görsel Motor & 92.00 & 3.12 & 92.40 & 2.45 & $.71^{*}$ \\
\hline & İnce Motor & 120.10 & 2.46 & 120.20 & 2.29 & $.91 * *$ \\
\hline & Kaba Motor & 155.40 & 7.41 & 155.30 & 7.51 & $.99 * *$ \\
\hline \multirow{3}{*}{$\begin{array}{l}48-95 \text { ay } \\
(\mathrm{N}=50)\end{array}$} & Görsel Motor & 80.24 & 12.06 & 80.50 & 12.31 & $.99 * *$ \\
\hline & İnce Motor & 114.18 & 6.98 & 114.42 & 6.75 & $.99 * *$ \\
\hline & Kaba Motor & 119.38 & 26.62 & 119.20 & 26.57 & $.99 * *$ \\
\hline
\end{tabular}

Tablo 14 incelendiğinde, 84-95 ay grubu Görsel Motor testinin iki ölçüm arası korelasyon katsayıs1 hariç tüm ölçümler arası korelasyon değerlerinin .91 ve üzeri olduğu görülmektedir. Tüm yaş gruplarında (48-95 ay) bakıldığında korelasyon değerinin tüm motor alanlar için .99 olduğu görülmektedir. Elde edilen korelasyon katsayıları Miller Fonksiyon ve Katılım Ölçeği’nin test tekrar test güvenirlik ölçütünü karşılar niteliktedir.

\section{Bağımsız Değerlendiriciler Arası Güvenirlik}

Miller Fonksiyon ve Katılım Ölçeği’nin bağımsız değerlendiriciler arası tutarlığının test edilmesinde ölçek ile ilgili eğitim verilmiş biri çocuk gelişimi uzmanı diğeri okul öncesi eğitimi uzmanı (araştırmacı) iki kişi bağımsız olarak her yaş grubundan iki çocuğun bulunduğu toplam 10 çocuğu puanlamışlardır. Ölçümler arası korelasyon Pearson Korelasyon Katsayısı ile test edilmiştir. İki puanlayıcı arası korelasyon katsayıları Tablo15’ de verilmiştir.

Tablo 15. Miller Fonksiyon ve Katılım Ölçeğı’nin bağımsız değerlendiriciler arası korelasyon katsayıları

\begin{tabular}{ll}
\hline Alt Testler & $\mathrm{r}$ \\
\hline Görsel Motor & $.99^{* *}$ \\
İnce Motor & $.99^{* *}$ \\
Kaba Motor & $.99 * *$ \\
\hline$* * \mathrm{p}<.01 ;(\mathrm{n}=10)$ &
\end{tabular}

Tablo 15 incelendiğinde, gözlenen grubun bağımsız değerlendiriciler arası korelasyon katsayılarının .99’un üzerinde olduğu görülmektedir. Bu korelasyon katsayıları, bağımsız değerlendiriciler aras1 uyumun yüksek olduğunu göstermektedir. 


\section{SONUÇ ve TARTIŞMA}

Bu bölümde, Miller Fonksiyon ve Katılım Ölçeği Türkçe formunun 48-95 ay arası çocuklar için geçerlik ve güvenirlik çalışmasına ilişkin sonuçlara ve tartışmaya yer verilmiştir. Araştırmanın geçerlik çalışmasında, Miller Fonksiyon ve Katılım Ölçeği'nin geliştirilmesi sırasında uygulanan geçerlik çalışmaları göz önünde bulundurulmuş ve testin geçerliği farklı yöntemlerle incelenmiştir. Öncelikle testin genel yapısı, ölçüm alanları ve bileşenleri ile teorik yapı uyumuna ilişkin uzman görüşüne dayalı olarak içerik geçerliği yapılmıştır. Uyarlama çalışmaları için öncelikle ölçeğin kullanma kılavuzu, değerlendirme tabloları ve kişisel kayıt formunun İngilizce orijinali akademik olarak iyi derecede İngilizce bilen Çocuk Gelişimi, Beden Eğitimi ile Fizyoterapi ve Rehabilitasyon alanlarında bir uzmana verilerek Türkçe’ ye çevirisi yapılmıştır. Çeviri metin Türkçe dil uzmanları tarafından incelenmiş ve gerekli düzenlemeler yapıldıktan sonra Mütercim-Tercümanlık Bölümü iki öğretim üyesi tarafından orijinal metinle karşılaştırılmıştır. İki çeviri arasında Miller Fonksiyon ve Katılım Ölçeği’nin güvenirliğini düşürebilecek bir farklılık gözlenmemiştir.

İçerik geçerliği için, Çocuk Gelişimi, Fizyoterapi ve Rehabilitasyon, Beden Eğitimi ve Spor, Sınıf Öğretmenliği alanında farklı üniversitelerde çalışmakta olan doktora derecesine sahip öğretim üyelerine ölçeğin orijinali ve Türkçe çeviri hali gönderilmiş ve uygulanacak çalışma grubuna uygunluğu açısından görüşleri istenmiştir. Alan uzmanlarından gelen görüşler doğrultusunda ölçek tekrar gözden geçirilerek gerekli uyarlama ve düzenlemeler yapılarak Türkçe Kayıt Formu ile Uygulama Yönergeleri kitabının son hali oluşturulmuştur. Ölçeğin Türkçe formunun 15 çocukla pilot uygulaması yapılmıştır. Pilot uygulamalarda, yönergelerin çocuklar tarafından anlaşılır olması, ölçeğin uygulanması sırasında yaşanabilecek olası durumlar değerlendirilerek kaydedilmiş ve gerekli düzenlemeler yapılmıştır. "Miller Fonksiyon ve Katılım Ölçeği’nin geliştirilmesi sırasında içerik geçerliği açısından, mevcut teoriler ve çalışma alanları (AOTA 2002, 2008; WHO 2001, 2007) temel alınarak genel yapısı, bileşenleri ve ölçüm alanları tasarlanmıştır. Miller Fonksiyon ve Katılım Ölçeği’nin faaliyetlerinin tamamı, okul öncesi ve ilkokul müfredatı, literatür taraması ve konu uzmanlarının bilgilerine dayanarak oluşturulmuştur. Faaliyetler, erken okul başarısına yol açan görevlerle ilgili olacak şekilde yapılandırılmıştır” (Miller, 2006).

Yap1 geçerliği analizlerinden elde edilen sonuçlara göre, Miller Fonksiyon ve Katılım Ölçeği motor gelişim alanlarının sıfır sıralı korelasyon sonuçlarının .71 ila .85 arasında değiştiği görülmekte ve bu değerler Miller Fonksiyon ve Katılım Ölçeği'nin tek bir temel yapıya sahip olduğunu göstermektedir. "Brychta, Sadílek ve Brychta (2016) hareketlerin sıklıkla kaba veya ince olarak sınıflandırılmış olsa da, çok azının tamamen sadece küçük ya da büyük kas grupları tarafından 
yönetilmekte olduğunu belirtmektedir. Her iki motor beceri türü de genellikle birlikte gelişir, çünkü birçok aktivite her iki becerinin koordinasyonuna bağlıdır. Görsel-motor bütünleşme ise el becerisi, hassasiyet, koordinasyon ve manuel kontrol dahil olmak üzere, el bileği ve elin küçük kaslarının kullanılmasını gerektiren ince motor becerilerini koordine etmek için görsel algılama sisteminden girdi kullanma becerisidir" (Schneck, 2010, akt: Doney et al., 2016, s. 347). Bu bilgiler, motor gelişimin ayrı alanları da olsa kaba, ince ve görsel motor becerilerin ilişki içerisinde olduğunu ve birbirini etkilediğini göstermektedir. Yaş değişkenini kontrol altında tutarak hesaplanan kısmi korelasyon sonucunun ise sıfır sıralı korelasyon sonuçlarına göre daha düşük oldukları (.32-.46) görülmüştür. Bu sonuç, Miller Fonksiyon ve Katılım Ölçeği'nin alt alanlarının (Görsel, İnce ve Kaba Motor) birbirleriyle hem ilişkili olduğu hem de motor gelişimin farklı yönlerini ölçtüğünü ortaya koymaktadır. Ölçeğin geliştirilmesi sırasında Miller (2006) tarafından yapılan yapı geçerliği çalışmasında ise, Görsel Motor ve Kaba Motor puanları .47, İnce Motor ve Kaba Motor puanları .58 , Görsel Motor ve İnce Motor puanları .55 olmak üzere motor gelissim alanları arasında bu çalışma ile benzer şekilde orta düzeyde korelasyon bulunmuştur.

Tepeli (2007) Büyük Kas Becerilerini Ölçme Testi (BüKBÖT)'nin standardizasyonu çalışmasında çocukların alt testlerden (nesne kontrol ve lokomotor) aldıkları puanların korelasyonunu incelemiştir. Üzerinde çalşılan norm grubundaki deneklerin iki alt testten aldıkları puanlar arası korelasyon .76'dır. Yaşlara göre incelendiğinde ise, bu çalışmadakine benzer şekilde korelasyon sonuçlarının daha düşük olduğu görülmüştür. 9 yaş dışında diğer bütün yaşlarda katsayılar ise makul düzeyde (.37-.61) bulunmuştur. Bu sonuçlar, BüKBÖT’ün alt testleri arasındaki korelasyon katsayılarının gereğinden fazla yüksek olması durumunda, alt testlerin aynı yeteneği aynı derecede ölçtügü; katsayılar çok düşük olsaydı alt testlerin büyük kas beceri gelişiminin ayırıcı yönünden çok, ilişkili olmayan yetenekleri ölçtüğü anlamına geleceği şeklinde yorumlanmıştır.

Miller Fonksiyon ve Katılım Ölçeği’nin zamandaş geçerliğini sınamak amacıyla farklı ölçme araçları ile uyumu incelenmiştir. Türkiye'de geliştirilmiş ya da uyarlaması yapılmış olan kaba, ince ve görsel motor alanlarının tümünü kapsayan tek bir ölçek bulunmadığı için iki farklı değerlendirme aracı kullanılmıştır. Miller Fonksiyon ve Katılım Ölçeği’nin İnce Motor ve Kaba Motor alanları için Gazi Erken Çocukluk Gelişimi Değerlendirme Aracı ile korelasyonu incelenmiştir. Ancak Gazi Erken Çocukluk Gelişimi Değerlendirme Aracı 0-72 ay çocuklara yönelik olduğu için çalışma grubu içinde yer alan 72 aylıktan büyük çocuklara uygulanamamıştır. Bu nedenle kaba ve ince motor alanlarında ölçüt geçerliğine sadece 48-72 ay arasındaki 30 çocuk dâhil edilmiştir. Ölçümler arası korelasyon yaş gruplarında Spearman-Brawn; tüm grupta ise Pearson Korelasyon Katsayısı ile test edilmiştir. Miller Fonksiyon ve Katılım Ölçeği'nin İnce Motor ve Kaba Motor alanlarının uyum geçerliği için 
çalışma grubunun Gazi Erken Çocukluk Gelişimi Değerlendirme Aracı'ndan aldıkları toplam puanlar ile Miller Fonksiyon ve Katılım Ölçeği toplam puanları arasında hesaplanan korelasyon 4871 ay çocuklarda İnce Motor alanı için .74 ( $p<.01)$; Kaba Motor alanı için ise .94 ( $<<.01)$ olarak bulunmuştur. Ölçümler arası korelasyona yaş gruplarına göre bakıldığında, 60-71 ay arası çocuklar dışında $.88 \quad(\mathrm{p}<.01)$ ve üzerinde olduğu görülmektedir. Gazi Erken Çocukluk Gelişimi Değerlendirme Aracı'ndan 60-71 ay arası çocukların aldıkları ince motor puanların dağılımı incelendiğinde, bu yaş grubundaki tüm çocukların testten alınabilecek en yüksek puanı aldıkları görülmüş; bu nedenle gözlenen puanların dağılım göstermemesinden ötürü bu yaş grubu için korelasyon testi sonuçları anlamlı bulunmamıştır. Miller Fonksiyon ve Katılım Ölçeği’nin Görsel Motor alanı için Frostig Gelişimsel Görsel Alg1 Testi ile korelasyonu incelenmiştir. Frostig Gelişimsel Görsel Alg1 Testi 3-9 yaş çocuklarına uygulanabildiği için görsel motor alanında tüm yaş grupları uyum geçerliği açısından incelenmiştir. Çalışmaya dahil edilen 48-95 ay arası 50 çocuğun Frostig Gelişimsel Görsel Alg1 Testi’nden aldıkları toplam puanlar ile Miller Fonksiyon ve Katılım Ölçeği görsel motor alanı toplam puanları arasında hesaplanan korelasyon .94’tür ( $\mathrm{p}<.01)$. Ölçümler arası korelasyon yaş gruplarında .68 ve .99 arasında değişmektedir.

Testin geliştirilmesi sırasında yapılan ölçüt geçerliği çalışmasında, 15 çocuktan oluşan örneklem grubunun Miller Fonksiyon ve Katılım Ölçeği puanları ile Miller Assessment of Preschoolers (MAP) puanları arasındaki korelasyon orta ve yüksek düzey arasında değişmektedir (0.47-0.83). Diemand (2009) tarafından yapılan Miller Fonksiyon ve Katılım Ölçeği’nin ölçüt geçerliği çalışmasında, 54 ve 78 ay arası toplam 40 çocuğun Developmental Test of Visual Perception, Second Edition (DTVP-2) puanları ile Miller Fonksiyon ve Katılım Ölçeği’nin Görsel Motor puanlarının korelasyonu incelenmiştir. İki test arasındaki korelasyon $(\mathrm{r}=.872$; $\mathrm{p}<.001)$ yüksek düzeyde bulunmuştur.

Miller Fonksiyon ve Katılım Ölçeği'nin gelişimsel geçerliğini incelemek amacıyla 48-95 ay aralığındaki çocukların görsel, ince ve kaba motor ham puanlarının yaş gruplanına göre karşılaştırılması için yapılan varyans analizi sonuçlarına göre tüm motor gelişim alanları yaş gruplarına göre anlamlı şekilde farklılaşmaktadır. Hangi yaş grupları arasında anlamlı farklılaşma olduğunu incelemek amaciyla yapılan çoklu karşılaştırma testleri sonucunda, 72-83 ay ve 84-95 ay arası çocukların İnce Motor puanları dışında tüm yaş grupları arasında anlamlı farklılık bulunmuştur $(\mathrm{p}<.05)$. Buna göre çocukların motor gelişimin alt alanlarından aldıkları ham puanların yaşa göre farklılaştı̆̆ görülmüştür. 
Zachopoulou ve Makri (2005) yaşın motor yaratıcıllı̆ın iki faktörü - motor akıcıllğı ve motor esnekliği - üzerindeki etkisini 191 çocuktan oluşan çalışma grubu ile incelemişlerdir. Varyans analizi sonuçları, hem motor yaratıcıllğı hem de motor esnekliği faktörü üzerinde üç yaş grubu arasında istatistiksel olarak anlamlı farklılıklar göstermiştir. Büyük çocuklar, küçük çocuklardan daha niceliksel ve niteliksel hareket tepkileri vermişlerdir. Boz (2011) çalışmasında, çocukların Büyük Kas Motor Gelişim Testi puanlarını yaş değişkenine göre incelemiş ve analiz sonuçları, büyük kas motor gelişim puanları arasında yaşa göre anlamlı bir fark olduğunu göstermiştir $[F(1,58)=106.987, p<.01]$. Diğer bir deyişle, 6 yaş çocukların motor gelişimleri 5 yaş çocuklara göre daha ileri düzeyde bulunmuştur. Bulgular doğrultusunda yaşın artmasıyla çocukların motor becerilerinde gelişme olduğu ifade edilmiştir. Öztoklu Durmuş (2014) araştırmasında, Beery-Buktenica Gelişimsel Görsel-Motor Koordinasyon Testi-6'nı Türkçe'ye uyarlanma çalışmalarını yapmış ve 36-70 aylık çocukların görsel-motor koordinasyonlarını yaş değişkenine ilişkin olarak incelemiştir. Varyans analizi sonuçları, çocukların yaş gruplarına göre görsel-motor koordinasyon testi puanlarının anlamlı bir şekilde farklılaştığını göstermiştir $\mathrm{F}(2.384)=203.249 ; \mathrm{p}<0.05$. Diğer bir deyişle, çocukların görsel-motor koordinasyon puanlarının yaş büyüdükçe arttığı görülmüştür.

Miller Fonksiyon ve Katılım Ölçeği'nin klinik ayırt edici geçerliğini incelemek amacıyla, tipik gelişim gösteren çocuklar ile motor gelişim gecikmesi olan çocukların ölçekten aldıkları görsel, ince ve kaba motor puanlarının karşılaştırılmasına ilişkin sonuçlar incelendiğinde, iki grubun tüm motor gelişim alanlarında puanlarının anlamlı düzeyde farklılaştı̆̆ görülmektedir $(\mathrm{p}<.01)$. Aynı zamanda puanlar motor gelişimin Görsel Motor ( 8 alt test), İnce Motor (5 alt test) ve Kaba Motor (6 alt test) alanlarının alt testleri dikkate alınarak incelenmiş ve tüm alt testlerde anlamlı farklılık bulunmuştur (p<.01). Bu sonuçlar, Miller Fonksiyon ve Katılım Ölçeği'nin 48-95 ay arası motor gecikmeleri olan çocukların belirlenmesinde kullanılabileceğine dair kanıt sağlamaktadır. Miller Fonksiyon ve Katılım Ölçeği’nin bir çocuğun görsel, ince ve kaba motor işleme alanında gecikmesi olup olmadığını belirlerken uygulayıcılar için geçerli bir değerlendirmede bulunduğunu göstermektedir. Ölçeğin geliştirilmesi sırasında Miller (2006) tarafindan yapılan klinik ayırt edici geçerlik çalışmasında, tipik motor gelişim gösteren grup ile motor gecikme gösteren tanı almış grup puanları arasındaki fark, her üç motor gelişim alanı için .01 düzeyinde anlamlı bulunmuştur. Motor gecikmeleri olan çocuklar, tipik gelişmekte olan çocuklara göre ortalama 3.98 ile 5.55 arasında daha düşük standart puan almışlardır. Diemand ve Case-Smith (2013) 54 ve 78 ay arası toplam 40 çocuğun, Miller Fonksiyon ve Katılım Ölçeği (M-FUN) veya Developmental Test of Visual Perception, Second Edition (DTVP-2) tarafından değerlendirildiğinde, aynı kategoriye (tipik olarak gelişen veya görsel motor gecikmeleri) yerleştirilmelerini belirlemek için ayırt edici analiz yapmışlardır. Araştırmaya katılan 20 çocuk "PDMS-2 Fine Motor Scale" ile tanı almış ve bu tanı doğrultusunda iş-uğraşı terapi 
hizmeti alan çocuklardır. Aynı zamanda ebeveyn ve öğretmenlerden edinilen bilgiler bu çocukların fonksiyonel bir görsel motor problemi olduğunun desteklemiştir. M-FUN ve DTVP-2, bir öğrencinin daha önce PDMS-2 tarafindan tanımlandığı gibi görsel motor fonksiyonu alanında bir yetersizliği olup olmadığını sınıflandırırken yüksek düzeyde bir uyum göstermiştir. DTVP-2, 40 (\% 85) öğrenciden 34'ünü; M-FUN ise, 36'sını doğru bir şekilde tanımlamıştır.

Araştırmanın güvenirlik çalışması kapsamında, Miller Fonksiyon ve Katılım Ölçeği’nin geliştirilmesi sırasında uygulanan güvenirlik çalışmaları göz önünde bulundurulmuş ve testin iç tutarlılık katsayısı, yaş gruplarına göre ölçmenin standart hatası, test tekrar test güvenirlik katsayısı ve bağımsız değerlendiriciler arası güvenirlik katsayısı incelenmiştir. Miller Fonksiyon ve Katılım Ölçeği’ndeki maddelerin iç tutarlılık güvenirliği Cronbach'ın alfa katsayısı kullanılarak araştırılmıştır. Miller Fonksiyon ve Katılım Ölçeği'nin alt alanlarının yaş gruplarına göre iç tutarlılık katsayıları incelendiğinde, 48-53 ay arası iç tutarlılık katsayıları Görsel Motor için .87, İnce Motor için .93, Kaba Motor için .92 bulunmuştur. 54-59 ay arası iç tutarlılık katsayıları Görsel Motor için .71, İnce Motor için .87, Kaba Motor için .89 bulunmuştur. 60-71 ay arası iç tutarlılık katsayıları Görsel Motor için .78, İnce Motor için .88, Kaba Motor için .87 bulunmuştur. $72-83$ ay arası iç tutarlllık katsayıları Görsel Motor için .61, İnce Motor için .71, Kaba Motor için .91 bulunmuştur. 84-95 ay arası iç tutarlılık katsayıları Görsel Motor için .65, İnce Motor için .75, Kaba Motor için .86 bulunmuştur. Ölçeğin geneli için bakıldığında, 48-95 ay arası iç tutarlılık katsayıları Görsel Motor için .91, İnce Motor için .90, Kaba Motor için .93 bulunmuştur. Cronbach alfa katsayısının yorumlanması için literatürde farklı sınıflamalar yer almaktadır. Tüm maddeler için elde edilen alfa değeri o testin toplam güvenirliğini gösterir ve yaygın kabul edilen yaklaşıma ait sınıflamaya göre genel kabul bu değerin 0.7 ve büyük olmasıdır (Kılıç, 2016, s. 47). Sonuçlar incelendiğinde 72-83 ay arası ve 84-95 ay arası Görsel Motor alanı dışında elde edilen tüm değerlerin bu ölçütü karşıladığı görülmektedir. "Güvenirlik, testlerin değil ölçümlerin bir özelliğidir (Caruso, 2000; akt, Bademci, 2004)” ifadesinden yola çıkarak, bu çalışma grubundan elde edilen ölçümlerde 72-83 ay arası ve 84-95 ay arası Görsel Motor alanında beklenen değerlere ulaşılamamasında, gözlenen puanların dağılım göstermemesinin etkili olduğu söylenebilir. Daha ayrışık (heterojen) örneklem gruplarının sıklıkla daha çok değişken ölçümlere ve bu durumda daha yüksek güvenirliğe yol açacağı dikkate alınarak testin Türkiye için norm çalışması yapılırken özellikle bu yaş gruplarında farklı sosyo-kültürel arka plana sahip, daha ayrışı bir çalışma grubuna ulaşılması faydalı olacaktır. Testin geliştirilme sürecinde Miller (2006) tarafindan yapılan güvenirlik çalışmasında, yaş gruplarına göre görsel motor alanı güvenirlik katsayıları incelendiğinde, .67 değeri ile 84-95 ay grubunda diğer yaş gruplarına göre korelasyon katsayısı daha düşüktür. İnce motor alanı güvenirlik katsayıları incelendiğinde de diğer yaş gruplarına göre 72-83 ay (0.79) ve 84-95 ay (0.85) grupları korelasyon katsayıları daha düşüktür. 
Tüm grupta ölçümler arası güvenirlik katsayıları Görsel Motor için 0.85, İnce Motor için 0.90 ve Kaba Motor için 0.92 bulunmuştur.

Miller Fonksiyon ve Katılım Ölçeği alt alanlarının çocukların yaşlarına göre ölçmenin standart hata puanları hesaplanmıştır. Test bir çocuğa uygulandığında, ortaya çıkan gözlemlenen puanlar, bazı hatalar içeren gerçek puanların tahminidir. Bu nedenle, bir testin ölçümünün standart hatası, kullanıcıların çocuğun elde ettiği puanın gerçek puanından ne kadar farklı olacağına dair bir fikir edinmelerine yardımcı olur (Miller, 2006). Testin Görsel Motor, İnce Motor ve Kaba Motor puanları için yaş gruplarına göre ölçümle ilişkilendirilmiş standart hata puanlarının düşük olduğu görülmüştür. Bu durum, yüksek test güvenirliği derecesini desteklemektedir.

Miller Fonksiyon ve Katılım Ölçeği’nden elde edilen ölçümlerin zamansal stabilitesini belirlemek amacıyla test-tekrar test güvenirliği $(n=50)$ korelasyon katsayıları hesaplanmıştır. Ölçeğin iki hafta ara ile yapılan uygulamaları sonucunda elde edilen puanların birbiriyle pozitif yönde anlamlı bir ilişki içinde olduğu görülmüştür (.71-.99). Elde edilen korelasyon katsayıları Miller Fonksiyon ve Katıllım Ölçeği’nin test tekrar test güvenirlik ölçütünü karşılar niteliktedir. Ölçeğin geliştirilmesi sırasında test-tekrar test güvenirliği için Miller (2006) tarafindan 48-95 ay arası toplam 28 çocuğa ortalama 14 gün arayla test uygulanmıştır. Korelasyon değeri, Görsel ve Kaba Motor alanları için .77, İnce Motor alanı için .82 bulunmuştur.

Miller Fonksiyon ve Katılım Ölçeği’nin bağımsız değerlendiriciler arası tutarlığının test edilmesinde ölçek ile ilgili eğitim verilmiş biri çocuk gelişimi uzmanı diğeri okul öncesi eğitimi uzmanı (araştırmacı) iki kişi bağımsız olarak her yaş grubundan iki çocuğun bulunduğu toplam 10 çocuğu puanlamışlardır. gözlenen grubun bağımsız değerlendiriciler arası korelasyon katsayıları her bir motor alan için .99 değerinde bulunmuştur. Bu korelasyon katsayıları, bağımsız değerlendiriciler arası uyumun yüksek olduğunu göstermektedir. Ölçeğin geliştirilmesi sırasında, bağımsız değerlendiriciler arası güvenirliği araştırmak için, 5 bağımsız değerlendirici 29 çocuğun test performansını değerlendirmiştir. Bir değerlendirici testi yönetmiş ve puanlamış, diğer değerlendiriciler çocuğun performansını gözlemlemiş ve bağımsız bir şekilde başka bir test protokolünde çocuğun yanıtlarını puanlamışlardır. Bağımsız değerlendiricilerin puanları arasındaki korelasyon, Görsel Motor için .91, İnce Motor için .93 ve Kaba Motor için .91 olarak bulunmuş ve testin üç motor alanının mevcut puanlama kuralları kullanılarak güvenilir bir şekilde puanlanabileceği ifade edilmiştir.

Bu sonuçlar doğrultusunda, Miller Fonksiyon ve Katılım Ölçeği’nin eğitimcilerin, çocuk gelişimi uzmanlarının, fizyoterapistlerin ve iş-uğraşı terapistlerinin 48-95 ay arası hem tipik gelişim gösteren 
hem de özel gereksinimli çocukların kaba, ince ve motor gelişimlerini sistematik ve çok boyutlu değerlendirmelerine; aynı zamanda gerekli eğitim, tedavi ve terapi amaçları geliştirebilmelerine olanak sağlayacağ ifade edilebilir.

\section{KAYNAKÇA}

Aral, N. ve Bütün Ayhan, A. (2016). Frostig Görsel Alg1 Testi’nin Türkçeye uyarlanması. The Journal of Academic Social Science Studies, 50, 1-22.

Bademci, V. (2004). " Testin güvenirliği" veya "Test güvenilirdir" diye ifade etmek doğru değildir. Türk Ë̆itim Bilimleri Dergisi, 2(3), 367-373.

Boz, M. (2011). 5-6 yass grubu çocuklara uygulanan temel hareket eğitim programmm hareket becerilerinin gelişimine etkisi. Yayımlanmamış Doktora Tezi, Gazi Üniversitesi, Eğitim Bilimleri Enstitüsü, Ankara.

Brychta, P., Sadílek, M., \& Brychta, J. (2016). The Influence of Motor Skills on Measurement Accuracy. Technological Engineering, 13(1), 19-21

Diemand, S. (2009). Validity of the Miller Function and Participation Scales. Degree of Master of Science in the Graduate School of the Ohio State University.

Diemand, S., \& Case-Smith, J. (2013). Validity of the miller function and participation scales. Journal of Occupational Therapy, Schools, \& Early Intervention, 6(3), 203-212.

Doney, R., Lucas, B. R., Watkins, R. E., Tsang, T. W., Sauer, K., Howat, P. et al. (2016). Visualmotor integration, visual perception, and fine motor coordination in a population of children with high levels of Fetal Alcohol Spectrum Disorder. Research in developmental disabilities, 55, 346-357.

Draper, C. E., Achmat, M., Forbes, J., \& Lambert, E. V. (2012). Impact of a community-based programme for motor development on gross motor skills and cognitive function in preschool children from disadvantaged settings. Early Child Development and Care, 182(1), 137-152.

Eather, N., Bull, A., Young, M. D., Barnes, A. T., Pollock, E. R., \& Morgan, P. J. (2018). Fundamental movement skills: Where do girls fall short? A novel investigation of objectcontrol skill execution in primary-school aged girls. Preventive medicine reports, 11, 191-195.

Erdoğanoğlu, Y. ve Kerem Günel, M. (2007). Serebral Paralizili Çocukların Motor ve Fonksiyonel Seviyeleri ile Sağlıkla İlgili Yaşam Kaliteleri Arasındaki İlişkinin İncelenmesi. Toplum Hekimliği Bülteni, 26 (3), 13-18.

Field, A. (2016). An adventure in statistics: The reality enigma. Sage.

Franzen, M. D. (2002). Reliability and V alidity in Neuropsychological Assessment. New York: Springer.

Gallahue, D. L., Ozmun, J. C. ve Goodway, J. D. (2014). Motor Gelişimi Anlamak. D. S. Özer ve A. Aktop (Çev Ed.). Ankara: Nobel Yayın Dağıtım. 
Gliner, J. A., Morgan, G. A., \& Leech, N. L. (2015). Uygulamada araștırma yöntemleri: Desen ve analiz̨i bütünleştiren yaklaşım (Çev.: Volkan Bayar, Çev. Ed.: Selahattin Turan). Ankara: Nobel Yayın Dağıtım.

Haywood, K., Roberton, M., \& Getchell, N. (2012). Advanced analysis of motor development. United States of America : Human Kinetics.

Hestbaek, L., Andersen, S. T., Skovgaard, T., Olesen, L. G., Elmose, M., Bleses, D., Andersen; S. C. \& Lauridsen, H. H. (2017). Influence of motor skills training on children's development evaluated in the Motor skills in PreSchool (MiPS) study-DK: study protocol for a randomized controlled trial, nested in a cohort study. Trials, 18(1), 1-11.

James, S., Ziviani, J., \& Boyd, R. (2014). A systematic review of activities of daily living measures for children and adolescents with cerebral palsy. Developmental Medicine \& Child Neurology, 56(3), 233-244.

Jurimae, T., \& Jurimae, J. (2001). Growth, physical activity, and motor development in prepubertal children. New York: CRC Press.

Karasar, N. (2006). Bilimsel araştırma yöntemi: Kavramlar, ilkeler, teknikler. (16. Baskı) Ankara: Nobel Yayın Dağıtım.

Kılıç, S. (2016). Cronbach's alpha reliability coefficient. Journal of Mood Disorders, 6(1), 47.

Lam, H. M. Y. (2011). Assessment of preschoolers' gross motor proficiency: revisiting BruininksOseretsky Test of Motor Proficiency. Early Child Development and Care, 181(2), 189-201.

Miller (2006). Miller Function \& Participation Scales: Administration directions. San Antonio, Texas: PsychCorp Pearson.

Öztoklu Durmuş, F. (2014). Beery-Buktenica Gelişimsel Görsel-Motor Koordinasyon Testi-6'nın Türkese'ye Uyarlanması ve 36-70 Aylık Çocuklarda Görsel Motor Koordinasyonun Incelenmesi. Yayımlanmamış Yüksek Lisans Tezi, Selçuk Üniversitesi, Sosyal Bilimler Enstitüsü, Konya.

Park, M. O. (2017). Effects of gross motor function and manual function levels on performancebased ADL motor skills of children with spastic cerebral palsy. Journal of physical therapy science, 29(2), 345-348.

Payne, V. G. ve Isaacs, L. D. (2012). Human motor development: A lifespan approach. (8. Bask1). New York: McGraw-Hill.

Sökmen, S. (1994). Beş yaş alg gelişimi (Frostig görsel algı testi güvenirlik çalıșması). Yayınlanmamış Yüksek Lisans Tezi, Marmara Üniversitesi, Sosyal Bilimler Enstitüsü, İstanbul.

Sugden, D. A. \& Wade, M. G. (2013). Typical and atypical motor development. London, England: Mac Keith Press.

Temel, F., Ersoy, Ö., Avc1, N., \& Turla, A. (2016). Gaz̧i erken çocukluk gelişimi değerlendirme aracı "GECDA”. Ankara: Hedef Yayıncillk. 
Tepeli, K. (2007). Büÿ̈̈k kas becerilerini ölçme testi (BüKBÖT)'nin Türkiye standardizasyonu. Yayımlanmamış Doktora Tezi, Selçuk Üniversitesi, Sosyal Bilimler Enstitüsü, Konya.

Tepeli, K. (2013). Frostig görsel alg1 eğitim programı ile birlikte verilen nesne kontrol beceri eğitiminin 54-59 aylık çocukların nesne kontrol becerilerine etkisi. Selçuk Üniversitesi Sosyal Bilimler Enstituisü Dergisi, (29), 251-260.

Zachopoulou, E. \& Makri, A. (2005). A developmental perspective of divergent movement ability in early young children. Early Child Development and Care, 175(1), 85-95.

Zysset, A. E., Kakebeeke, T. H., Messerli-Bürgy, N., Meyer, A. H., Stülb, K., Leeger-Aschmann, C. S., Schmutz, E. A., Arhab, A., Ferrazzini, V., Kriemler, S., Munsch, S., Puder, J. J. \& Jenni, O. G. (2018). The validity of parental reports on motor skills performance level in preschool children: a comparison with a standardized motor test. European journal of pediatrics, 177(5), 715-722. 